\title{
Physiological/pathological ramifications of transcription factors in the unfolded protein response
}

\author{
Jaeseok Han ${ }^{1}$ and Randal J. Kaufman ${ }^{2}$ \\ ${ }^{1}$ Soonchunhyang Institute of Medi-Bio Science (SIMS), Soonchunhyang University, Cheonan-si, Choongchungnam-do 31151, \\ Republic of Korea; ${ }^{2}$ Degenerative Diseases Program, Sanford Burnham Prebys Medical Discovery Institute, La Jolla, California, \\ 92307 USA
}

\begin{abstract}
Numerous environmental, physiological, and pathological insults disrupt protein-folding homeostasis in the endoplasmic reticulum (ER), referred to as ER stress. Eukaryotic cells evolved a set of intracellular signaling pathways, collectively termed the unfolded protein response (UPR), to maintain a productive ER protein-folding environment through reprogramming gene transcription and mRNA translation. The UPR is largely dependent on transcription factors (TFs) that modulate expression of genes involved in many physiological and pathological conditions, including development, metabolism, inflammation, neurodegenerative diseases, and cancer. Here we summarize the current knowledge about these mechanisms, their impact on physiological/pathological processes, and potential therapeutic applications.
\end{abstract}

The endoplasmic reticulum (ER) is the cellular organelle for protein folding and maturation, lipid and sterol biosynthesis, and calcium storage. ER homeostasis is disrupted by a number of insults that cause the accumulation of unfolded or misfolded proteins in the ER lumen, thereby activating the unfolded protein response (UPR) (Schroder and Kaufman 2005; Bernales et al. 2006). The UPR has outputs designed to couple the ER protein-folding capacity with demand so that the cell can survive and function. In order to increase protein-folding capacity, the homeostatic UPR expands the dimensions of the ER through increased biogenesis of protein and lipid components, including the protein translocation machinery, proteins that buffer folding reactions (chaperones), and trafficking machinery. Concurrently, the combined outputs of the homeostatic UPR increase transcription of ER-resident enzymes and structural components that increase protein-folding capacity and lead to the removal and degradation of misfolded proteins from the ER lumen in processes

[Keywords: ER stress; transcription factors; unfolded protein response] Corresponding authors: rkaufman@sbpdiscovery.org, hanjs015@sch.ac.kr Article is online at http://www.genesdev.org/cgi/doi/10.1101/gad.297374. 117. Freely available online through the Genes \& Development Open Access option. termed ER-associated degradation (ERAD) and macroautophagy (referred to here as autophagy). Of note are the penultimate effector transcription factors (TFs) in UPR signaling that activate or inhibit expression of target genes. Given the importance of TFs in the UPR, it is necessary to understand how these TFs function. Here, we describe the role of TFs involved in the UPR and how they contribute to human pathologies (Wang and Kaufman 2016).

\section{ER stress and the UPR}

The ER is the site where proteins destined for the cell surface and the endomembrane system enter the secretory pathway (Kaufman 1999). Approximately one-third of all proteins are translocated across the ER membrane in an unfolded state, where they subsequently fold into their proper three-dimensional structures and are subject to glycosylation, hydroxylation, lipidation, and disulfide bond formation (Kaufman 1999, 2002; Ron 2002). The ER contains a high $\mathrm{Ca}^{+2}$ concentration and is occupied by chaperone proteins and enzymes that facilitate folding and post-translational modifications (Schroder and Kaufman 2005). Only properly folded proteins traffic to the Golgi compartment for further processing before transport to their final destination. Protein folding in the ER is disrupted by numerous insults, including pharmacological perturbations, genetic mutation of ER chaperones or their client proteins, elevated expression of proteins that transit the endomembrane system, viral infection, alterations in $\mathrm{Ca}^{2+}$ or redox status, differentiation of cells that secrete large amounts of proteins, and decreases as well as increases in available nutrients. The accumulation of unfolded or misfolded proteins in the ER lumen activates the UPR (Schroder and Kaufman 2005; Bernales et al. 2006). The UPR is signaled through three ER transmembrane proteins: inositol-requiring enzyme $1 \alpha$

(C) 2017 Han and Kaufman This article, published in Genes \& Development, is available under a Creative Commons License (Attribution 4.0 International), as described at http://creativecommons.org/licenses/ by $/ 4.0 /$. 
(IRE1 a), PKR (dsRNA-activated protein kinase)-related ER protein kinase (PERK), and activating TF 6a (ATF6a) (Scheuner and Kaufman 2008; Walter and Ron 2011). All three UPR sensors are maintained in an inactive state through interaction between their ER luminal domains and the protein chaperone immunoglobulin heavy chain-binding protein (BiP; also known as GRP78 and HSP5A). Upon ER stress and loss of ER homeostasis, accumulated unfolded/misfolded proteins in the ER lumen bind and sequester BiP, thereby promoting dissociation of BiP from IRE1a, PERK, and ATF6a (Bertolotti et al. 2000; Shen et al. 2002; Ali et al. 2011). ER stress sensors that are dissociated from $\mathrm{BiP}$ induce their downstream TFs through unique mechanisms described below.

\section{Activation of TFs in the UPR}

In response to ER stress, the cell undergoes vast transcriptional reprograming by inducing or activating TFs. Following activation of proximal ER stress transducers, the activities of basic leucine zipper (bZIP)-containing TFs increase though preferential translation (e.g., ATF4), unconventional mRNA splicing (e.g., XBP1), or regulated intramembrane proteolysis (RIP; e.g., ATF6a) (Fig. 1). Other TFs in the UPR, including ATF3, CHOP /C/EBP [CCAT enhancer-binding protein] homologous protein), and ATF5, are induced through either preferential translation or conventional transactivation by ATF4, which binds to C/EBP ATF response elements (CAREs) in the promoter regions of target genes (Kilberg et al. 2009). The activities of additional TFs, including NFkB, increase due to a reduction in inhibitor levels as a consequence of translational attenuation mediated by eukaryotic initiation factor $2 \alpha$ (eIF2a) phosphorylation (Jiang et al. 2003; Deng et al.
2004). Some TFs, including c-JUN, c-FOS, EGR-1, and cMYC, known as immediate early genes, are induced at very early time points after eIF2 a phosphorylation, but their functions and induction mechanisms are unknown (Liang et al. 2006b).

\section{Preferential mRNA translation}

During eukaryotic mRNA translation, the small ribosomal subunit (40S) is preloaded with Met-tRNAi by the GTPbound form of eIF2 to form a $43 \mathrm{~S}$ preinitiation complex (PIC). The 43S PIC binds the $5^{\prime}$ end of the mRNA and scans the $5^{\prime}$ untranslated region (UTR) until it encounters an AUG codon in a favorable Kozak consensus context (Kozak 1991) joining to a 60S ribosomal subunit coupled with eIF2-mediated GTP hydrolysis to GDP. Conversion of eIF2 to its GDP-bound state reduces its affinity for Met-tRNAi, causing it to dissociate from the PIC for recycling. To perform another round of initiation, eIF2B is required to promote GTP exchange for GDP on eIF2. Phosphorylation at Ser51 in eIF2 a greatly increases the affinity of eIF2 for GDP, thereby preventing the eIF2B catalyzed exchange reaction and sequestering eIF2B with eIF2 in an inactive complex, resulting in global attenuation of mRNA translation. Paradoxically, translation of several mRNAs, including ATF4, is preferentially enhanced due to the presence of upstream ORFs (uORFs) (Harding et al. 2000; Kaufman 2004; Lu et al. 2004; Vattem and Wek 2004). ATF4 mRNA encodes a uORF (uORF1) for a three-amino-acid peptide, and the second UORF (uORF2) encodes a 59-amino-acid residue peptide that overlaps with the first 83 nucleotides (nt) of the ATF4-coding region (Vattem and Wek 2004). After synthesis of the uORF1-encoded polypeptide, ribosomes continue scanning along the ATF4 mRNA. When eIF2 $\alpha-G T P$ is highly

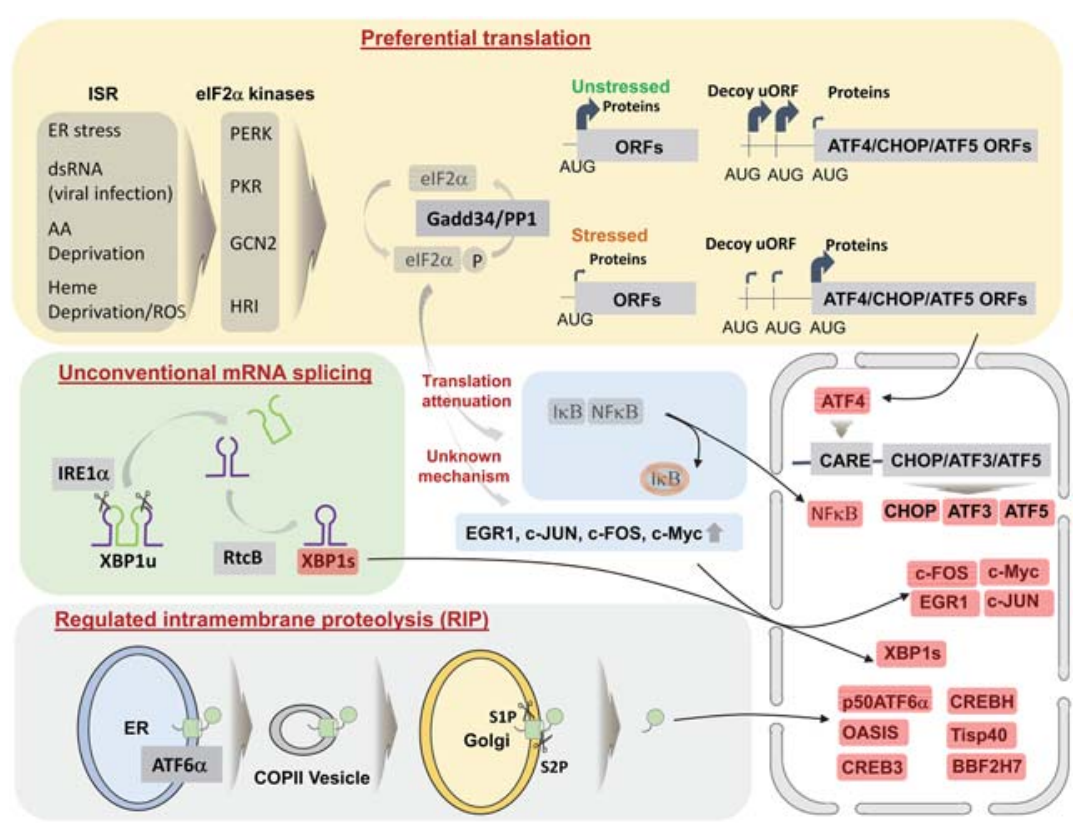

Figure 1. Activation of TFs in the UPR. Upon stresses, activated eIF2 $\alpha$ kinases phosphorylate eIF2 $\alpha$ that is dephosphorylated Gadd34/PP1. Although phosphorylated eIF2 $\alpha$ attenuates general mRNA translation, some TFs, including ATF4, CHOP, and ATF5, are preferentially translated. ATF4 then translocates into the nucleus to activate the promoter region harboring CARE motifs. During translational attenuation, I $\mathrm{KB}$, an inhibitor of NF- $\mathrm{kB}$, is depleted(due to its short half-life) to activate NF- $\mathrm{kB}$. In addition, eIF2 $\alpha$ phosphorylation induces some TFs involved in the immediate early response, including EGR1, c-JUN, c-FOS, and cMyc, through an unknown mechanism. XBP1 mRNA cleaved by IREla is ligated by RTCB to generate functional XBP1s mRNA. Unlike PERK and IRE1 $\alpha$, ATF6 $\alpha$ released from BiP translocates to the Golgi apparatus through COPII vesicles, where the cytoplasmic region is cleaved by site-1 protease $(\mathrm{S} 1 \mathrm{P})$ and S2P. CREBH (cAMP response element-binding protein $\mathrm{H}$ ), OASIS (old astrocyte specifically induced substance), Tisp40 (transcript induced in spermiogenesis), CREB3, and BBF2H7 (BBF2 human homolog on chromosome 7) are also activated through this mechanism. 
available in the absence of phosphorylated eIF2 $\alpha$, ribosomes reinitiate translation at UORF2, which overlaps out of frame with a portion of the ATF4-coding region, thereby reducing ATF4 translation. During ER stress conditions, the reduced amounts of available eIF2 $\alpha$-GTP permit an increase in time for scanning ribosomes to reinitiate, causing scanning ribosomes to bypass the initiation codon of the inhibitory uORF2. Thus, the scanning ribosomes associate with available eIF2a-GTP-MettRNAi to allow enhanced translation of ATF4. Although translation of some mRNAs, including CHOP (Palam et al. 2011), GADD34 (Lee et al. 2009), and ATF5 (Watatani et al. 2008), is up-regulated upon eIF2 $\alpha$ phosphorylation, the mechanisms appear different from that of ATF4. For example, the 5' UTR of CHOP has one uORF with a poor Kozak initiation context that might be bypassed by scanning ribosomes upon eIF2 a phosphorylation. Consequently, scanning ribosomes would initiate at the $C H O P$-coding region that has a strong Kozak motif (Palam et al. 2011). Nevertheless, almost half of human transcripts contain one or more uORFs, suggesting that translational regulation at the initiation step has a pivotal role in the cellular response to ER stress (Barbosa et al. 2013; Hinnebusch et al. 2016). Indeed, a report describing the translational landscape in cancer indicated that translation from unconventional AUG codons may significantly impact cancer initiation (Sendoel et al. 2017). In addition, the potential for therapeutic intervention by targeting uORF translation was demonstrated recently (Liang et al. 2016).

\section{eIF2 $\alpha$ kinases}

There are four protein kinases that are dedicated to phosphorylating eIF2 $\alpha$ at Ser51 (Fig. 1). The first identified was the heme-regulated inhibitory kinase (HRI) described in reticulocyte lysates. It functions to inhibit protein synthesis in reticulocytes upon heme deprivation in order to prevent misfolding of globin (Han et al. 2001). The second is the general control nonderepressible kinase (GCN2) that is activated by uncharged tRNAs to couple protein synthesis with amino acid availability (Sood et al. 2000). The third is PKR that is activated by dsRNA to prevent viral replication as part of the interferon response (Williams 1999). Finally, PERK evolved to respond to the accumulation of misfolded proteins in the ER to inhibit further production of misfolded proteins (Harding et al. 1999). The sum of these responses, all of which regulate translation through phosphorylation of eIF $2 \alpha$, was termed the integrated stress response (ISR). However, since different stresses all converge on eIF2 $\alpha$-P, increased mRNA translation cannot be assumed to be a consequence of ER stress.

Unconventional mRNA splicing To obtain functional transcriptional activity, $X B P 1$ or yeast $H A C 1$ mRNA requires splicing initiated by IRE1. Upon activation by ER stress, IRE1 is autophosphorylated, which elicits its RNase activity to cleave $H A C 1$ or XBP1 mRNA. While translation of unspliced HAC1 mRNA is blocked by its intron in yeast, in metazoans, unspliced $X B P 1$ mRNA is efficiently translated to produce XBP1u, which binds the active TF XBP1s to enhance its degradation (Tirosh et al. 2006; Yoshida et al. 2006). In contrast to conventional splicing, which is catalyzed by the spliceosome and involves a consensus sequence at the exon and intron border junctions, such as GU-AG or AU-AC (Tarn and Steitz 1997), splicing of HAC1 and XBP1 is composed of a twostep unconventional splicing reaction. In yeast cells (Saccharomyces cerevisiae), activated Irelp cleaves the unspliced HAC1 mRNA at two RNA stem-loops to excise an intervening 252-base intron, and then the tRNA ligase Trllp joins the two exons followed by removal of the junctional 2 ' phosphate in the second step by 2 ' phosphotransferase Tpt 1p, generating the spliced form of HAC1 mRNA (Sidrauski et al. 1996; Sidrauski and Walter 1997; Schwer et al. 2004). Similarly, in metazoans, IRE 1 a first removes a 23-nt (Caenorhabditis elegans and Drosophila melanogaster) or 26-nt (mammals) intron from the unspliced XBP1 mRNA (Tirasophon et al. 1998; Shen et al. 2001; Yoshida et al. 2001; Calfon et al. 2002), and the proximally located tRNA ligase RTCB joins the two cleaved XBP1 exons to generate a mature mRNA to produce the spliced form of XBP1 (Kosmaczewski et al. 2014; Lu et al. 2014). XBP1 mRNA appears to be the only substrate for IRE1a for splicing, as sophisticated searches for other substrates have failed (Bai et al. 2014).

RIP Processing of ATF6a is different from the mechanisms by which ATF4 and XBP1s are induced. ATF6a is a type II transmembrane protein composed of a luminal domain that senses protein misfolding and a cytoplasmic DNA-binding portion containing a bZIP domain and transcriptional activation domain (Haze et al. 1999). Upon release from $\mathrm{BiP}$, Golgi localization signals in its ER luminal region are exposed, and then ATF6a translocates to the Golgi apparatus, where it is cleaved by Golgi-resident proteases-first site-1 protease (S1P) and then S2Pto release the N-terminal bZIP TF domain (p50ATF6a) (Haze et al. 1999; Ye et al. 2000; Chen et al. 2002; Shen et al. 2002). These are the same processing enzymes that cleave the sterol-regulated element-binding proteins (SREBPs). In addition to ATF6a, several bZIP TFs located in the ER membrane are regulated by RIP. Those TFs include the cAMP response element-binding protein $\mathrm{H}$ (CREBH or CREB3L3) (Zhang et al. 2006), old astrocyte specifically induced substance (OASIS) (Kondo et al. 2005), BBF2 human homolog on chromosome 7 (BBF2H7) (Kondo et al. 2007), transcript induced in spermiogenesis $\alpha / \beta$

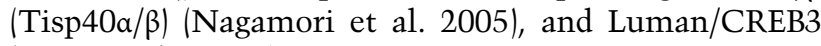
(Liang et al. 2006a).

\section{Diverse roles of UPR TFs}

Deletion and/or forced expression studies in different cell types demonstrate that each of these TFs provides unique and essential functions in response to ER stress (Table 1). Deletion of either Ire 1 a or Xbp1 causes embryonic lethality because they are largely important for differentiation 
Table 1. Target genes of transcription factors and their functions

\begin{tabular}{|c|c|c|c|c|c|}
\hline & Target Tissues/Cells & Function/Phenotype & & Target Tissues/Cells & Function/Phenotype \\
\hline ATF4 & & & CHOP & & \\
\hline Development & & & Development & & \\
\hline Angpt13 & Fetal liver & HSC self-renewal & Unknown & HSC & Survival/death balance of HSC \\
\hline Rsk2 & Bone & Bone development & Metabolism & & \\
\hline Bglap2 & Osteoblast & Osteoblast maturation & Unknown & $\beta$ cells & Oxidative stress induced $\beta$-cell death \\
\hline Tnfsf11 & Osteoclast & Osteoclast lineage commitment & NF-кb & $\beta$ cells & Proinflamatory response in $\beta$ cells \\
\hline \multirow[t]{2}{*}{ Not defined yet } & Lens cells & Lens cell survival & Unknown & Liver & Stress induced hepatocyte death \\
\hline & & & Cebpa & Liver & Impaired hepatic lipid metabolism \\
\hline Metabolism & & & Cebpb, Pparg & Adipocytes & Inhibition of adipogenesis \\
\hline FoxO1 & Osteoblast & Osteoblast-mediated glucose homeostasis & Inflammation & & \\
\hline Scd 1 & Liver & Lipid accumulation & IL-6 & Various cells & Proinflammatory response \\
\hline Srebp lc, Acc, Fas & Liver & Hepatic lipid metabolism & $\mathrm{IL}-8$ & $\mathrm{~T}$ cells, hepatocytes & Proinflammatory response \\
\hline Not defined yet & Hypothalamus & Insulin resistance & IL-23p 19 & Dendritic cells & TLR-mediated IL-23 production/secretion \\
\hline Fgf21 & Muscle & Increased insulin sensitivity & Unknown & Lung tissue & $\begin{array}{l}\text { Procaspase-1 and Pro-IL-1 } \beta \text { processing } \\
\text { Inflammasome activation }\end{array}$ \\
\hline Inflammation & & & Neurodegerative diseases & & \\
\hline Mcp1, Tnfa & Various cells & Enhanced inflammation & Unknown & Dopaminergic neuron & Neuronal cell death (PD development) \\
\hline Stat3 & Retinal cells, retina & Retinal inflammation & Cancer & & \\
\hline 116 & Macrophage & Proinflammatory response & Tnfrsf10b & Various cancers & Cancer cell death \\
\hline NLRP1 & Macrophage & Inflammasome activation & Transferrin & Hepatoma cells & Inhibition of cancer cell survival \\
\hline Neurodegerative diseases & & & Il6, Stat3 & MDSC & Tumor progression \\
\hline Psen 1 & Brain & Induction of $\gamma$-secretase (AD development) & XBP1s & & \\
\hline Ddit3 & Hipocampal neuron & Neuronal cell death (AD development) & Metabolism & & \\
\hline Park2 & Dopaminergic neuron & Neuronal cell survival & Ire $1 \alpha$ & $\beta$ Cells & $\beta$-Cell suvival \\
\hline Trib3 & Dopaminergic neuron & Neuronal cell death (PD development) & Pdxl, Mafa & $\beta$ Cells & $\beta$-Cell dys function and apoptosis \\
\hline Cancer & & & Foxo 1 & Hepatocytes & Suppression of gluconeogenesis \\
\hline Cdkn2a & MEFs & Oncogenic transformation & Ppara & Hepatocytes & Induction of $\beta$-oxidation and ketogenesis \\
\hline Mcll & Multiple myeoloma & Multiple myeloma resistance to bortezomib & Dgat2, Scd1, Acc2 & Hepatocytes & Enhanced lipogenesis and hepatosteatosis \\
\hline Ulk1 & Brest cancer & Cancer survival & $\mathrm{P} 85$ and $\mathrm{P} 85 \beta$ & Hepatocytes & Insulin signaling and metabolic homeostasis \\
\hline Hmoxl & Firbrosarcoma & Metastasis promotion & Neurodegerative diseases & & \\
\hline Mmp2 & ESCC & Invasion and metastasis promotion & Unknown & Dopaminergic neuron & Pathogenic effect on PD during development \\
\hline Stat3 & ESCC & Multidrug resistance & Unknown & Dopaminergic neuron & Protective effect on PD in adult \\
\hline Bbc3, Pmaip 1, Trib3 & Neuroblastoma & Cancer cell death & RyR3 & Neuron & Prevention of $A \beta$ neurotoxicity \\
\hline Tnfrsf10b & AML & Cancer cell death & Foxo 1 & Neuron & Progression of Huntington's disease \\
\hline Hdac4 & Multiple myeoloma & Cancer cell survival & Unknown & Neuron & Reduction of Htt protein aggregation \\
\hline ATF3 & & & Unknown & Motor neuron & Promotion of ALS pathogenesis \\
\hline Metabolism & & & Inflammation & & \\
\hline Gluconeogenesis genes & Liver & Defective glucose homeostas is & Not defined yet & Lymphoid system & Maintenance of adaptive immune responses \\
\hline Not defined yet & Pancreatic endocrine & Defective endocrine cell proliferation & Gata1 & Eosinophil & Eosinophil development \\
\hline Adipoq, Adipor1 & Adipocytes & Insulin resistance & Not defined yet & Intestinal epithelium & Maintenance of intestinal inflammation \\
\hline Pepck & Hepatocytes & Reduced gluoneogenesis & Not defined yet & Paneth cells & Paneth cells development and survival \\
\hline Irs2, Pdxl & Pancreatic $\beta$ cells & $\beta$-cell dysfunction & Cancer & & \\
\hline Inflammation & & & Not defined yet & Various cancers & Promoting cancer progression \\
\hline 116 & Macrophages & Suppression of inflammation & Hifla & Breast cancer & Promoting tumorigenesis \\
\hline I112b & APC & Suppression of TLR pathway & Snail & Breast cancer & Epithelial-to-mesenchymal transition (EMT) \\
\hline $\mathrm{Cc} 14$ & Macrophages & Prevention of excessive inflammation & $\begin{array}{l}\text { Lipid metabolism- } \\
\text { related genes }\end{array}$ & Tumor-associated DC & Suppresion of anti-tumor immunity in DC \\
\hline Ifnb1 & Macrophages & Suppression of IFN responses & Stat3 & Colitis-associated cance & erTumor suppression \\
\hline Inflammatory genes & Macrophages & HDL-mediated anti-inflammatory response & ATF6 $\alpha$ & & \\
\hline II23 & Dendritic cells & Anti-inflammatory response & Metabolism & & \\
\hline Cxcl1 & Lung epithelia & Inhibition of neutrophil recruitment & Cebpa & Liver & Hepatic lipid metabolism \\
\hline Neurodegerative diseases & & & ERAD genes & Liver & Hepatic lipid metabolism \\
\hline Not defined yet & Motor neuron & Neuronal survival & Neurodegerative diseases & & \\
\hline Cancer & & & Grp78 & Neuron & Neuronal homeostasis \\
\hline $\mathrm{p} 53$ & Squamous skin cancer & Tumorigenesis & ERAD genes & Dopaminergic neuron & Proteostasis \\
\hline Tgfb & Brest cancer & Epithelial-to-mesenchymal transition & Cancer & & \\
\hline Androgen receptor & Prostate cancer & Prostate cancer development & Ube2c, Cdkn3 & Hepatocarcinoma & Tumor development \\
\hline P53 & Cervical cancer & Tumor suppression & Rheb & Squamous carcinoma & Tumor survival \\
\hline Mdm2 & ESCC & Inhibition of cell invasion & Grp78 & Glioblastoma & Cancer cell survival \\
\hline Tnfrsflob & Colorectal cancer & Cancer cell apoptosis & & & \\
\hline AP1 & Glioblastoma & Inhibition of oncogenesis & & & \\
\hline Gsn & Bladder cancer & Suppression of metastasis & & & \\
\hline Tip60 & Various cells & Maintenance of genomic stability & & & \\
\hline
\end{tabular}

Genes in red are negatively regulated by TFs.

of cell types that secrete large amounts of protein, such as plasma cells that produce antibodies (Reimold et al. 2001; Iwakoshi et al. 2003; Zhang et al. 2005). In contrast, Atf6 $\alpha$ deletion has no apparent phenotype in mice in the absence of ER stress; however, these mice cannot adapt to protein misfolding in the ER (Wu et al. 2007). Thus, this arm likely promotes an adaptive response to acute ER stress. Genes activated by XBP1s and ATF6a have largely complementary and overlapping functions, including ER protein folding, degradation, and trafficking (Yamamoto et al. 2007). Finally, the TFs downstream from phosphorylated eIF2 $\alpha$, ATF4, and CHOP activate unique and overlapping sets of genes that induce expression of ER chaperones, ER protein degradation, amino acid metabolism, the antioxidant response, and restoration of protein synthesis. The latter can lead to cell death if protein misfolding persists (Han et al. 2013a). In most case studies, the role of these TFs in promoting ER homeostasis has been delineated; however, it remains largely unknown how basal levels of these TFs act in the absence of UPR 
activation. Here, we summarize fundamental and diverse roles of these TFs in pathological processes.

\section{ATF4}

Development Studies suggest a pivotal role for ATF4 in maintaining stem cell integrity. Atf4 deletion significantly impairs hematopoietic development and reduces hematopoietic stem cell (HSC) self-renewal due to decreased transcription of cytokine genes, including Angptl3 in fetal livers that serves as an important and unique site for rapid amplification of functional HSCs during development (Masuoka and Townes 2002; Zhao et al. 2015). Coffin-Lowry syndrome (CLS) is an X-linked mental retardation condition associated with skeletal abnormalities caused by a mutation in the protein kinase RSK2 gene. ATF4 is a critical substrate of RSK2, and deletion of Atf4 delays bone formation during embryonic development and decreases bone mass throughout postnatal life (Yang et al. 2004). ATF4 forms heterodimers with its critical partner, C/EBP $\beta$, which is a bZIP TF, acts on the osteocalcin (Bglap2) promoter, and is essential for osteoblast maturation (Tominaga et al. 2008). ATF4 is positively regulated by a stress-activated protein kinase, JNK (Matsuguchi et al. 2009); fibroblast growth factor 2 (FGF2) (Fei et al. 2010); and the ubiquitous TF Forkhead box O1 (FoxO1) during osteoblast differentiation (Rached et al. 2010). Another study also suggests that microRNA miR-214 reduces the amount of ATF4 protein but not mRNA levels to inhibit osteoblast function (Wang et al. 2013a). ATF4 also regulates osteoclast differentiation and ultimately bone resorption through expression in osteoblasts. ATF4 binds to the promoter and activates expression of the receptor activator of NF- $\kappa$ B ligand (RANKL; Tnfsf11). RANKL is a factor secreted by osteoblasts that binds to its receptor (RANK) on osteoclasts to trigger intricate and distinct signaling cascades that control osteoclast lineage commitment and activation (Cao et al. 2010). Thereby, ATF4 promotes bone formation.

At $f 4^{-/-}$mice display microphthalmia due to a complete absence of the lens through massive and synchronous apoptosis of the anterior epithelial lens (Hettmann et al. 2000). ATF4 is expressed at high levels in the anterior epithelial lens cells at embryonic day 14.5. The defective lens formation in the absence of ATF4 is not due to qualitative defects in the expression of lens-specific genes, including Pax-6, aA-crystallin, c-Maf, or PDGF-Ra, but rather the death of $A t f 4^{-/-}$epithelial lens cells is mediated by a p53-dependent apoptotic pathway, suggesting an essential role of ATF4 in retinal cell survival. However, overexpression of ATF4 in Xenopus laevis embryos interfered with neurogenesis and eye formation, suggesting that tightly controlled ATF4 expression may be crucial for normal eye patterning (Liu et al. 2011).

Metabolism Atf4 ${ }^{-/-}$mice exhibit a lean phenotype and resistance to diet-induced obesity, with lower levels of circulating carbohydrates (Seo et al. 2009). Although Atf4 ${ }^{-/-}$ mice did not exhibit an obvious defect in pancreatic $\beta$ cells
(Back et al. 2009), ATF4 seems to regulate glucose metabolism in mice by regulating osteoblast function (Kode et al. 2012). Atf4 deletion in mice improved glucose and insulin sensitivity, which was abolished by overexpression of ATF4 in osteoblasts through cooperation with FoxO1 (Kode et al. 2012). Furthermore, Atf4 deletion specifically in murine osteoblasts causes the same metabolic phenotypes as $A t f 4^{-/-}$mice, suggesting a requirement of ATF4 in osteoblast-mediated glucose homeostasis (Yoshizawa et al. 2009).

ATF4 appears to promote liver steatosis. Mice fed a high-carbohydrate diet (HCD) accumulate hepatic triglycerides (TGs) and display impaired glucose tolerance, which is diminished in the absence of ATF4 (Li et al. 2011). In the livers of Atf $4^{-/-}$mice fed a HCD, stearoylCoA desaturase 1 (SCD1) expression is markedly lower than wild-type livers, and overexpression of ATF4 restores levels of SCD1 and increases hepatic lipid accumulation (Li et al. 2011). Lipid accumulation caused by a high-fructose diet (HFrD) is also attenuated in $\mathrm{Atf4^{-/- }}$ mice due to decreased levels of three key genes in the lipogenic pathway, including sterol regulatory element-binding protein 1c (SREBP1c), acetyl-CoA carboxylase (ACC), and fatty acid synthase (FAS), suggesting a role for ATF4 in promoting hepatic lipid accumulation in response to nutritional stimuli (Xiao et al. 2013).

An association between ATF4 and insulin sensitivity is also evident. Overexpression of ATF4 in the hypothalamus induces hepatic insulin resistance in mice, and inhibition of ATF4 by expressing dominant-negative ATF4 has the opposite effect. Furthermore, inhibition of ATF4 in the hypothalamus reverses insulin resistance caused by ER stress in the brain, suggesting that ER stress causes hepatic insulin resistance through ATF4 (Zhang et al. 2013). On the other hand, ATF4 increases insulin sensitivity in mice. Elimination of autophagy selectively in muscle reduces diet-induced obesity and insulin resistance by promoting ATF4-mediated induction of FGF21 expression (Kim et al. 2013). It is unclear why ATF4 expression in the hypothalamus causes insulin resistance but in the muscle increases insulin sensitivity.

Inflammation ER stress and subsequent UPR activation are implicated in inflammatory responses that contribute substantially to disease progression (Zhang and Kaufman 2008; Hotamisligil 2010). In ER stress-mediated inflammation, ATF4 increases expression of inflammatory cytokines, including interleukin-6 (IL-6) and monocyte chemoattractant protein-1 (MCP-1), by inducing transcription of the NACHT, LRR, and PYD domain-containing protein 1 (NLRP1), a core component of the inflammasome. In response to ER stress, ATF4 binds to the promoter and induces expression of NLRP1, providing evidence that ATF4 induces an inflammatory response (D'Osualdo et al. 2015). ER stress caused by high glucose in endothelial cells induces inflammatory factors, including tumor necrosis factor- $\alpha$ (TNF- $\alpha$ ) and MCP-1, which is reduced by inhibiting ATF4 activity (Caselli et al. 2012; Chen et al. 2012; Wang et al. 2014; Huang et al. 2015). Forced expression of ATF4 induces endothelial 
inflammation through activation of STAT3-mediated cytokine production. Down-regulation of ATF4 significantly attenuates retinal inflammation in type 1 diabetic models (Chen et al. 2012). ATF4 is also implicated in the saturated fatty acid (SFA)-induced IL-6 expression in macrophages (Iwasaki et al. 2014). Attenuation of ATF4 in macrophages markedly inhibits SFA-induced IL-6 expression, whereas forced expression of ATF4 enhances IL-6 expression through direct activation of the IL-6 promoter and/or activation of NF- $\kappa B$ (Iwasaki et al. 2014).

Neurodegenerative disease ATF4 expression is increased in the hippocampus of Alzheimer's disease (AD) murine models and the axons from AD cadavers, suggesting a potential role of ATF4 in the spreading of AD pathology (Baleriola et al. 2014; Ohno 2014). ATF4 increases the expression of human presenilin-1 (PS1), an important subunit of the $\gamma$-secretase responsible for $A \beta$ production during $\mathrm{AD}$ pathogenesis (Mitsuda et al. 2007). Local application of A $\beta 1-42$ causes axonal synthesis of ATF4 and subsequent induction of $\mathrm{CHOP}$, leading to neuronal cell death. This phenomenon was abolished by knockdown of ATF4 expression (Baleriola et al. 2014).

Treatment with 6-hydroxydopamine (6-OHDA), a drug that induces a Parkinson's-like disease (PD), increases expression of several UPR genes, including ATF4, suggesting a potential role for ER stress in PD (Holtz et al. 2005). One of contributing factors for PD development is loss of the E3 ubiquitin ligase Parkin in dopaminergic neurons. The expression of Parkin is induced by ER stress through direct binding of ATF4 to the promoter region of the Parkin gene (Bouman et al. 2011). Given the protective role of Parkin, these results suggest that ATF4 promotes dopaminergic cell survival during PD pathogenesis. Consistently, ATF4 levels are increased in neurons in the substantia nigra in a subset of PD patients compared with controls (Sun et al. 2013). In addition, ATF4 overexpression in cellular models of PD reduces cell death, whereas silencing of ATF4 enhances cell death caused by 6-OHDA. In contrast, tribbles pseudokinase 3 (Trib3), a proapoptotic factor in the UPR, is transcriptionally induced by ATF4 in a cellular PD model upon 6OHDA treatment, suggesting a proapoptotic role for ATF4 in PD pathogenesis (Aime et al. 2015). Analysis of PD in mice with Atf4 deletion in dopaminergic neurons should provide greater insight into the role of ATF4 in PD.

Cancer Increased ATF4 expression was observed in murine and human tumor tissues (Ameri et al. 2004; Bi et al. 2005; Ye et al. 2010). Increased ATF4 expression facilitates tumorigenesis by modulating transcription of genes involved in tumor cell proliferation. ATF4 suppresses the expression of the cellular senescence-associated gene Cdkn2a (cyclin-dependent kinase inhibitor 2a) to drive oncogenic transformation (Horiguchi et al. 2012) and enhances expression of the anti-apoptotic gene myeloid cell leukemia-1 (Mcl-1) (Hu et al. 2012), the autophagy-initiating kinase Ulk1 (Pike et al. 2013), and heme oxygenase 1 (Hmox-1) (Dey et al. 2015) to promote cancer cell sur- vival. In addition, ATF4 causes cell invasion and metastasis by inducing matrix metalloproteinase 2 (Mmp2) (Zhu et al. 2014b). ATF4 also promotes multidrug resistance (MDR) expression, a major challenge to cancer treatment, through transactivation of signal transducer and activator of transcription 3 (Stat3) (Zhu et al. 2014a).

In contrast, other studies implicate ATF4 in an apoptotic response in tumors. Glutamine depletion selectively induces apoptosis in oncogenic MYC-overexpressing cells through ATF4-dependent induction of proapoptotic proteins PUMA and NOXA (Qing et al. 2012). The anti-cancer drug ONC201 induces tumor cell death through ATF4-mediated transactivation of the proapoptotic protein TRAIL and its receptor, death receptor 5 (DR5) (Ishizawa et al. 2016). ATF4-driven expression of CHOP is enhanced by a histone deacetylase (HDAC) inhibitor, thereby enhancing apoptosis upon proteasome inhibitor treatment (Kikuchi et al. 2015).

As discussed above, basal expression of ATF4 is indispensable for bone and eye development as well as metabolic homeostasis. The role of ATF4 upon ER stress is different in each tissue, likely due to the diversity of binding partners that form heterodimers under different conditions. In addition, the diversity of ATF4 downstream target genes might be another explanation for the different downstream responses. Therefore, identification of binding partners or target genes of ATF4 under different conditions will provide valuable insight toward understanding the complexities of the role of ATF4.

\section{ATF6 $\alpha$}

Metabolism ATF6a is essential for transcriptional induction of ER molecular chaperones as well as components of ERAD. Although Atf6a $a^{-/-}$mice display no apparent developmental phenotype under normal growth conditions, Atf6a deletion severely impairs liver function and prolongs steatosis compared with wild-type mice upon ER stress (Wu et al. 2007; Rutkowski et al. 2008; Yamamoto et al. 2010). This might result from prolonged CHOP expression in response to chronic UPR activation and consequent suppression of C/EBPa (Rutkowski et al. 2008) as well as reduced expression of chaperones and ERAD functions (Wu et al. 2007; Yamamoto et al. 2010). On the other hand, forced expression of the functionally active nuclear fragment of ATF6 in zebrafish causes fatty liver (Howarth et al. 2014), suggesting that fine-tuning of ATF6a may be important to prevent liver steatosis.

The role of ATF6a in the pathogenesis of human disease is also evident in diabetes, particularly in insulin-producing pancreatic $\beta$ cells. Single-nucleotide polymorphisms exist in a functionally important region of the ATF6a gene that is associated with type 2 diabetes in a population of Pima Indians (Thameem et al. 2006), Dutch Caucasians (Meex et al. 2007), and Chinese (Gonzalez-Rodriguez et al. 2014). Moreover, high-fat diet (HFD)-fed Atf6a ${ }^{-/-}$mice displayed glucose intolerance, blunted insulin secretion, and reduced pancreatic insulin content due to $\beta$-cell 
failure (Usui et al. 2012). In type 1 diabetes, there is a progressive loss of ATF6a expression before the onset of diabetes in nonobese diabetic (NOD) mice as well as in pancreata from type 1 diabetic patients, suggesting that ATF6 a protects $\beta$ cells (Engin et al. 2013). Curiously, the diabetic phenotype in murine models was recovered by treatment with the chemical chaperone taurourosodeoxycholic acid (TUDCA). Chemical chaperones are proposed to buffer protein folding in the ER that reduces ER stress. However, the beneficial effect of TUDCA treatment in NOD mice was abolished in the absence of ATF6a specifically in $\beta$ cells, suggesting that TUDCA protects $\beta$ cells from ER stress-mediated cell death in an ATF6a-dependent manner. This intriguing result needs further investigation because if TUDCA prevents accumulation of misfolded proteins, it would not be expected to activate ATF6a. It was demonstrated recently that hypomorphic mutations in ATF6a in humans cause a rare syndrome, achromatopsia, that is associated with age-onset color blindness and loss of cone photoreceptors in the retina (Ansar et al. 2015; Kohl et al. 2015; Chiang et al. 2017). Intriguingly, ATF6a deletion did not affect the function of rod photoreceptors, indicating a very selective requirement for ATF6a in cone photoreceptors.

Neurodegenerative disease ATF6a also plays an important role in neurodegeneration. For example, 6-OHDA-induced PD enhances activation of the PERK/eIF2 $\alpha$ pathway as well as ATF6a, and Atf6a ${ }^{-1-}$ mice exhibit accelerated neuronal degeneration and ubiquitin accumulation due to reduced expression of $\mathrm{BiP} / \mathrm{GRP} 78$, an ATF6 $\alpha$-dependent molecular chaperone in the ER (Hashida et al. 2012). Furthermore, impaired ATF6a signaling decreases ERAD function and increases proapoptotic signaling in PD animal models (Credle et al. 2015), suggesting that proteostasis maintained by ATF6a is critical to prevent PD.

Cancer Elevated expression of ATF6a is observed in human hepatocellular carcinoma (Shuda et al. 2003). ATF6a transactivates target genes that include ubiquitin-conjugating enzyme E2C (UBE2C) and CDKN3, which promote tumorigenesis (Arai et al. 2006). Polymorphisms in ATF6a are associated with increased expression and hepatocellular carcinoma (Wu et al. 2014). On the other hand, ATF6a prolongs survival of dormant tumor cells, but not proliferative squamous carcinoma cells, through transactivation of the Ras homolog enriched in brain (Rheb; a critical activator of the mammalian target of rapamycin [mTOR]) and thus activation of mTOR signaling (Schewe and Aguirre-Ghiso 2008). Similarly, ATF6a protects glioblastoma cells from UV-induced cell death by transactivating $\mathrm{BiP}$, suggesting proto-oncogenic effects of ATF6a. Finally, as $\mathrm{BiP}$ expression frequently correlates with tumor status, chemoresistance, and prognosis (Lee and Hendershot 2006; Wang and Kaufman 2014) and as ATF6a is the primary driver of $\mathrm{BiP}$ expression, targeting $\mathrm{BiP}$ expression via the ATFT6 a pathway should be considered a therapeutic approach for cancer (Gutierrez and Simmen 2014; Obacz et al. 2017).
In contrast to other UPR TFs, ATF6a is not necessary to maintain the physiological state, since Atf $6 a^{-/-}$mice do not exhibit overt phenotypes. The primary function of ATF6a is likely to protect cells from acute ER stress; however, its target genes are yet to be clearly identified due to the absence of suitable antibodies for ChIP-seq (chromatin immunoprecipitation [ChIP] combined with highthroughput sequencing) analyses. Future studies, including ChIP-seq and RNA sequencing (RNA-seq), will identify sets of genes regulated by ATF6a, which will provide insight into the function of ATF6a.

\section{ATF3}

Metabolism Overexpression of ATF3 inhibits expression of gluconeogenesis genes in the liver and also causes aberrations in the endocrine pancreas with reduced hormone-producing cells in the islets, resulting in defective glucose homeostasis (Allen-Jennings et al. 2002). ATF3 decreases expression of adiponectin (Kim et al. 2006) and the adiponectin receptor (Park et al. 2010a) in adipocytes, phosphoenolpyruvate carboxykinase (PEPCK) in hepatocytes (Allen-Jennings et al. 2002), and the insulin receptor substrate 2 (IRS2) (Li et al. 2008) and pancreatic and duodenal homeobox factor $1(\mathrm{PDX} 1)$, a key differentiation factor for pancreatic development (Jang et al. 2011), in pancreatic $\beta$-cells. Mice lacking ATF3 exhibit defects in $\beta$-cell function with reduced insulin secretion upon a HFD (Zmuda et al. 2010). Therefore, proper regulation of ATF3 expression appears critical to maintain differentiated cell function.

Inflammation ATF3 is induced during Toll-like receptor (TLR)-dependent immune responses and represses expression of numerous proinflammatory cytokines, including IL- 6 and IL-1 $\beta$, by altering chromatin structure to restrict access to TFs such as NF- $\kappa \mathrm{B}$ in macrophages (Gilchrist et al. 2006; Whitmore et al. 2007). ATF3 also modulates the expression of macrophage inflammatory protein 1 (MIP-1, also known as CCL4) in macrophages, thereby preventing excessive inflammation (Khuu et al. 2007). ATF3 decreases IFN responses by controlling basal and inducible levels of IFN- $\beta$ and expression of IFN target genes in macrophages (Labzin et al. 2015). Thus, Atf3-lmice are more susceptible to endotoxic shock due to excessive cytokine production (Hoetzenecker et al. 2012). ATF3 also mediates high-density lipoprotein (HDL)-induced anti-inflammatory reprogramming of macrophages by transcriptional repression of inflammatory genes (De Nardo et al. 2014). In neutrophils, ATF3 restricts neutrophil recruitment by reducing neutrophil chemokine production that promotes neutrophil chemotaxis (Boespflug et al. 2014). ATF3 also suppresses the IL-23 pathway in dendritic cells to exert an IL-4-mediated anti-inflammatory effect (Whitmore et al. 2007; Guenova et al. 2015).

Neurodegenerative disease Amyotrophic lateral sclerosis (ALS) is an adult-onset degenerative disorder of motor neurons. Intact adult motor neurons do not 
normally express ATF3. However, ATF3 expression is observed in spinal motor neurons in an ALS murine model that harbors a transgene-expressing human cytosolic superoxide dismutase 1 with an ALS-associated mutation (hSOD1G93A) (Malaspina et al. 2010). Interestingly, forced expression ATF3 promotes neuronal survival and delays the ALS phenotype in hSODG93A transgenic mice (Seijffers et al. 2014), suggesting that ATF3 is protective in ALS.

Cancer Accumulating evidence suggests that ATF3 plays a pivotal role in cancer development by regulating the balance between survival and cell death. As a protooncogene, ATF3 expression is elevated in human breast cancer (Yin et al. 2008), malignant human prostate cancer (Pelzer et al. 2006), malignant Hodgkin's lymphoma (Janz et al. 2006), and squamous cell carcinoma (Wu et al. 2010). ATF3 reduces expression of tumor suppressor p53 and its downstream target genes in squamous cell carcinoma $/ \mathrm{Wu}$ et al. 2010) and transactivates expression of TGF $\beta$ genes in breast cancer (Yin et al. 2010). In addition, ATF3 represses androgen-dependent genes by inhibiting androgen activity, resulting in prostate cancer development (Wang et al. 2012a).

In contrast to the above results, ATF3 expression is decreased in human colorectal cancer (Bottone et al. 2003), cervical cancer (Wang et al. 2010), and glioma (Gargiulo et al. 2013) compared with normal tissues, suggesting that ATF3 may act as a tumor suppressor. ATF3 activates p53 by preventing its ubiquitination and degradation in cervical cancer (Wang et al. 2010). ATF3 also increases expression of MDM2 to facilitate MMP-2 degradation and subsequent inhibition of cell invasion in esophageal squamous cell carcinoma (Xie et al. 2014). In colorectal cancer, ATF3 activates DR5 to enhance sensitivity to apoptotic cell death (Taketani et al. 2012; Edagawa et al. 2014). In addition, bone morphogenetic protein (BMP) signaling activates ATF3 to bind open chromatin structures at AP1preloaded sites and inhibit the oncogenic network (Gargiulo et al. 2013). ATF3 also suppresses bladder cancer metastasis through promoting gelsolin-mediated actin remodeling (Yuan et al. 2013) and maintains genomic stability by activating ataxia telangiectasia mutated (ATM) signaling (Cui et al. 2015).

It is not clear how ATF3 acts in a dichotomous nature in cancer development. It is possible that stress-inducible ATF3 is involved in p53-dependent target gene expression and apoptosis, whereas tumor-related ATF3 suppresses proapoptotic genes in the p53 pathway (Taketani et al. 2012). These results suggest that ATF3 has cell contextdependent effects on p53 target genes in the stress response and cancer development. However, the exact mechanism of ATF3 in transformation and the role of p53 remain to be elucidated. As many tumors are p53-negative, this is an important question.

Although the function of ATF3 extends to other physiological responses, ATF3 appears to play a role mainly in inflammation and cancer. It is noteworthy that ATF3 expression is highly induced by not only ER stress but oxidative stress and DNA damage. It is not known whether this induction is mediated by eIF2a phosphorylation or P53. Thus, the role of ATF3 should be interpreted based on the combined effects of these stimuli.

\section{CHOP/DDIT3/GADD153}

Development Since Chop ${ }^{-/-}$mice are born without developmental defects, it seems that CHOP is not necessary for embryonic development. However, HSCs from Chop $^{-/-}$mice exhibit increased viability, suggesting that CHOP may be required for the survival/death balance of mouse HSCs under physiological conditions (van Galen et al. 2014). The role of CHOP in development or differentiation of stem cells remains to be elucidated.

Metabolism Chop deletion in $\beta$ cells is protective in several diabetic murine models. In heterozygous Akita mice, which exhibit a diabetic phenotype due to a misfolding mutation (Cys96Tyr) in the insulin 2 gene, disruption of the Chop gene delays the onset of diabetes (Oyadomari et al. 2002). In both genetic (leptin receptor deficient $d b / d b$ mice) and HFD-induced type 2 diabetic murine models, Chop deletion improves $\beta$-cell ultrastructure, function, and survival, suggesting that CHOP is a fundamental factor that links ER stress to apoptosis in $\beta$ cells under conditions of increased insulin demand in type 2 diabetes (Song et al. 2008). Chop deletion also protects $\beta$ cells from cytokine-induced proinflammatory responses by reducing cytokine-induced NF- $\mathrm{BB}$ activity (Allagnat et al. 2012). The exact mechanism by which CHOP mediates $\beta$-cell death is not clear, but evidence suggests that oxidative stress caused by ER protein misfolding significantly contributes to $\beta$-cell death (Song et al. 2008; Li et al. 2010; Han et al. 2013a, 2015).

CHOP is also involved in liver dysfunction upon ER stress. Chop deletion protects mice from various hepatocyte-specific challenges, including bile duct ligation (Tamaki et al. 2008), acetaminophen (Uzi et al. 2013), alcohol feeding (Ji et al. 2005), and diet-induced steatohepatitis (Rinella et al. 2011; Toriguchi et al. 2014). In contrast to the beneficial effect of Chop deficiency, Chop ${ }^{-/-}$mice fed a methionine-choline-deficient (MCD) diet display increased liver damage (Soon et al. 2010), possibly explained by a net accumulation of activated macrophages due to decreased death in the absence of CHOP (Malhi et al. 2013). As all of these studies were performed with ubiquitous Chop deletion, mechanistic insight is limited.

In addition to cell death, CHOP also is involved in hepatic lipid metabolism. ER stress induces CHOP that suppresses C/EBP $\alpha$ activity and other lipid master regulatory genes (Rutkowski et al. 2008). Consistently, Chop ${ }^{-/-}$ mice exhibit less hepatic lipid accumulation than wildtype mice upon treatment with human immunodeficiency virus (HIV) protease inhibitors (Wang et al. 2013b).

$\mathrm{CHOP}$ is also involved in adipocyte differentiation. As a dominant-negative inhibitor of $\mathrm{C} / \mathrm{EBPa}$ and $\mathrm{C} / \mathrm{EBP} \beta$ (Ron and Habener 1992), CHOP expression inhibits adipocyte differentiation under stress conditions (Batchvarova et al. 1995; Han et al. 2013b). It seems that 
CHOP sequesters and inhibits $\mathrm{C} / \mathrm{EBP} \beta$ activity to attenuate adipogenesis (Tang and Lane 2000). Transient CHOP expression in the early phase of differentiation of 3T3L1 cells (Tang and Lane 2000) completely inhibits adipogenesis (Han et al. 2013b), suggesting that strict regulation of $\mathrm{CHOP}$ is essential for adipocyte differentiation.

Inflammation CHOP is involved in inflammatory processes through the regulation of cytokine expression. $\mathrm{CHOP}$ promotes $I 16$ gene expression at the transcriptional level indirectly through dimerization with an inhibitory isoform of C/EBP $\beta$ (LIP) to prevent binding to the $I 16$ promoter (Hattori et al. 2003). On the other hand, following prostaglandin stimulation of T cells, $\mathrm{CHOP}$ directly binds to and induces the CXCL8 (also know as IL8) promoter (Cucinotta et al. 2008). Consistently, SFA-damaged hepatocytes secrete IL-8, which causes liver inflammation, contributing to the pathogenesis of nonalcoholic steatohepatitis (NASH) (Willy et al. 2015). CHOP binds to and induces expression of IL-23p19, a key mediator of inflammation in dendritic cells (Goodall et al. 2010). Infection of myeloid cells with bacteria induces CHOP transcription with subsequent induction of IL-23, which is greatly attenuated by knockdown of CHOP. In addition, activation of procaspase- 1 and pro-IL- $1 \beta$ is attenuated by Chop deletion in LPS-treated lungs of mice due to impaired induction of caspase-11, suggesting that CHOP mediates ER stress-mediated inflammasome activation (Endo et al. 2006). Thus, CHOP appears to regulate the immune response at multiple levels in different cell types.

Neurodegenerative disease CHOP expression is induced in human neuroblastoma SH-SY5Y cells in vitro as well as in substantia nigra dopaminergic neurons treated with 6-OHDA in vivo, suggesting that $\mathrm{CHOP}$ contributes to PD development (Silva et al. 2005; Yamamuro et al. 2006). Angiotensin II receptor blockade decreases dopaminergic cell death caused by 6-OHDA by down-regulating CHOP expression (Wu et al. 2013). In addition to $\mathrm{PD}, \mathrm{CHOP}$ expression is also markedly induced in brains from mice with $\mathrm{AD}$ (Lee et al. 2010a). Silencing of CHOP in the rabbit hippocampus protects animals from AD induced by 27 -hydroxycholesterol, an oxidized metabolite of cholesterol (Prasanthi et al. 2011). In contrast to the apoptotic role of $\mathrm{CHOP}$ in $\mathrm{AD}$ and $\mathrm{PD}$, constitutive overexpression of CHOP in myelinating cells under normal or ER stress conditions does not drive cell death (Southwood et al. 2016).

Cancer CHOP expression in tumors correlates with stage, malignancy, and low survival in patients (Kim et al. 2012; Dalton et al. 2013). The incidence of K-ras (G12V)-induced lung cancer is markedly enhanced in the absence of CHOP (Huber et al. 2013), suggesting an anticancer activity of CHOP. As a well-known proapoptotic gene, CHOP is considered a drug target for cancer (Schonthal 2013). Elevated expression of CHOP is observed in tumors after chemotherapy or as a consequence of uncontrolled growth of malignant cells (Schonthal 2013; Flaherty et al. 2014). Upon drug treatment, CHOP induction enhances apoptosis through transactivation of DR5 in human carcinoma (Yamaguchi and Wang 2004), prostate cancer (Shiraishi et al. 2005), pancreatic cancer (Abdelrahim et al. 2006), and lung cancer (Lin et al. 2008). CHOP also inhibits the expression of transferrin, a key protein for cell survival in hepatoma cells, decreasing tumor cell viability (You et al. 2003).

On the other hand, CHOP promotes hepatic carcinogenesis by enhancing inflammation, fibrosis, and cell death in the liver (DeZwaan-McCabe et al. 2013). In addition, Chop ${ }^{-1-}$ mice display smaller tumor nodules with reduced numbers of macrophages and levels of IFN $\gamma$. Since hepatocellular carcinoma is induced by chronic inflammation, CHOP may promote tumorigenesis by modulating the tumor microenvironment and macrophage recruitment to the tumor (Scaiewicz et al. 2013). Furthermore, Chop deficiency promotes the anti-tumor activity of tumor-infiltrating myeloid-derived suppressor cells (MDSC) by decreasing IL-6 and phospho-STAT3, delaying tumor progression (Thevenot et al. 2014). Unfortunately, many in vivo studies of CHOP use whole-body knockout mice, so it is not possible to understand the mechanistic basis for a phenotype.

Of all of the known TFs that function downstream from ER stress, CHOP is the only one that, when deleted, protects cells from cell death upon protein misfolding in the ER. However, the exact mechanism by which CHOP induces cell death remains unclear. Although several death-related genes are reported as targets of CHOP, they were not characterized by ChIP-seq analysis (Han et al. 2013a). This finding might result from different contexts of heterodimeric TFs that function with CHOP at different states or stages of differentiation or cancer, respectively. Therefore, it is essential to identify binding partners of CHOP to uncover unknown issues.

\section{$X B P 1$}

Metabolism $\beta$-Cell-specific Xbp1 deletion causes $\beta$-cell loss and reduces insulin content due to impaired proinsulin processing and constitutive hyperactivation of IRE1a that was proposed to degrade a subset of mRNAs encoding proinsulin processing enzymes (Lee et al. 2011a) in a process called IRE1 $a$-dependent RNA degradation (RIDD) (Kaser et al. 2008; Han et al. 2009; Lee et al. 2011a). IRE1 a hyperactivation typically occurs in cells that are deleted in XBP1. Developmental $\beta$-cell-specific Ire $1 \alpha$ deletion also causes $\beta$-cell failure (Xu et al. 2014). However, Ire $1 \alpha$ deletion in mature mice does reduce $\beta$ cell mass or expression of $\beta$-cell-specific genes, but glucose-stimulated proinsulin mRNA translation is defective primarily due to reduced glucose-stimulated induction of genes involved in proinsulin cotranslational translocation into the ER and signal peptide processing (Hassler et al. 2015). In contrast, sustained expression of XBP1s causes $\beta$-cell dysfunction and apoptosis through reduced expression of PDX1 and MAFA (Allagnat et al. 2010). Therefore, fine-tuning of XBP1s expression is necessary to maintain $\beta$-cell function. 
In hepatocytes, XBP1s is required for glucose and lipid homeostasis. Hepatic overexpression of XBP1s suppresses gluconeogenesis through its interaction with FoxO1 to promote its degradation through the $26 \mathrm{~S}$ proteasome system (Zhou et al. 2011). On the other hand, upon prolonged fasting, XBP1s directly induces expression of PPARa, the master regulator of the starvation response, leading to fatty acid $\beta$-oxidation and ketogenesis in the liver (Shao et al. 2014). XBP1s was reported to directly induce transcription of lipogenic genes in the liver, including Dgat2, Scd1, and Acc2 (Lee et al. 2008). Mx1-Cre mediated Xbp1 deletion in the liver causes profound defects in de novo hepatic lipogenesis, reducing serum TG, cholesterol, and free fatty acids. In contrast, lipogenesis is not induced, but very lowdensity lipoprotein (VLDL) assembly and secretion are impaired upon Ire1a Ad-Cre-mediated deletion in hepatocytes, causing hepatosteatosis and hypolipidemia (Zhang et al. 2011; Wang et al. 2012c). The defect in VLDL secretion is partly due to reduced expression of protein disulfide isomerase (PDI), a transcriptional target of XBP1s. PDI is essential for the activity of microtriglyceride transfer protein (MTP) that promotes TG uptake into the smooth ER (Wang et al. 2015). Xbp1 deletion by $M \times 1$ Cre also causes deletion in Kupffer cells (Lee et al. 2008), whereas Ad-Cre-mediated or albumin-Cre-mediated Ire 1a deletion is restricted to hepatocytes, and this may explain why lipogenic gene expression is not reduced in the latter cases (Zhang et al. 2011; Wang et al. 2012c). This emphasizes that the particular Cre used for tissuespecific deletion may significantly impact the phenotype. Therefore, it is desirable to analyze deletion promoted by two independent Cre drivers. Consequently, it remains unknown how ER stress affects lipid accumulation or secretion through the IRE1 1 /XBP1 pathway.

$\mathrm{XBP} 1 \mathrm{~s}$ is also involved in insulin signaling in the liver. $\mathrm{P} 85 \alpha$ and $\mathrm{p} 85 \beta$, regulatory subunits of phosphoinositide 3 kinase (PI3K), interact with XBP1s and increase its nuclear translocation. $p 85 a$ deletion in the liver reduces the UPR due to decreased XBP1s accumulation in the nucleus (Winnay et al. 2010). The interaction between p85a and XBP1s is lost in leptin-deficient $o b / o b$ mice, causing defective nuclear XBP1s translocation and an inability to resolve ER stress in obese mice (Park et al. 2010b).

Inflammation $\mathrm{XBP} 1$ was first discovered as a regulatory protein that binds to the X-box element within the human major histocompatibility complex (MHC) class II locus (Liou et al. 1988). Deletion of Ire1a or Xbp1 in the lymphoid system impairs adaptive immune responses, especially plasma cell differentiation responsible for antibody production (Reimold et al. 2001; Tirosh et al. 2005; Zhang et al. 2005), and decreases dendritic cells (Iwakoshi et al. 2007). In addition, XBP1 induces expression of the major lineage determinant GATA-1 that is necessary for eosinophil, but not basophil or neutrophil, differentiation (Bettigole et al. 2015), indicating its pivotal role in immune cell development.

$\mathrm{XBP} 1 \mathrm{~s}$ is also actively involved in inflammation. Xbp1 deletion in intestinal epithelial cells (IECs) causes ER stress and defects in Paneth cell function, leading to spon- taneous enteritis and increased susceptibility to colitis (Kaser et al. 2008; Adolph et al. 2013). However, IEC-specific Ire1a deletion does not cause defects in Paneth cells or intestinal dysplasia and even corrects defects in $X b p 1$-null Paneth cells. Therefore, Xbp1 deletion causes hyperactivation of IRE $1 \alpha$, leading to intestinal defects. In macrophages, TLR4 and TLR2 activate the IRE1 $\alpha-\mathrm{XBP} 1$ pathway, leading to sustained production of proinflammatory cytokines (Martinon et al. 2010). Indeed, myeloid-specific Ire1a deletion reduces inflammatory responses in a murine model of rheumatoid arthritis; however, IRE1 $\alpha$ activation did not occur as a response to ER stress but rather TLR activation (Qiu et al. 2013).

Neurodegenerative disease Developmental Xbp1 deletion in the murine nervous system protects dopaminergic neurons from 6-OHDA treatment (Valdes et al. 2014), suggesting a pathogenic role for XBP1 in PD pathology. Therefore, a low-level UPR activation may produce an adaptive response during neuronal development to maintain protein homeostasis in the absence of XBP1 signaling. In contrast, down-regulation of XBP1 expression in adult substantia nigra pars compacta (SNpc) induces strong ER stress that triggers massive dopaminergic neuron degeneration. In addition, delivery of XBP1s into the SNpc of adult mice protects dopaminergic neurons from 6-OHDA /Valdes et al. 2014). Similar to PD, XBP1 suppresses A $\beta$ neurotoxicity in the Drosophila eye and in cultured neurons by attenuating expression of the ryanodine receptor RyR3 to decrease $\mathrm{Ca}^{2+}$ release into the cytosol (Casas-Tinto et al. 2011). Xbp1 deletion delays progression of Huntington's disease (HD) by increasing autophagy to degrade the mutant Huntingtin $(\mathrm{Htt})$ protein. XBP deficiency promotes autophagy by augmenting expression of FoxO1, encoding a key TF for autophagy in neurons (Vidal et al. 2012). However, viral delivery of XBP1s into the striatum reduced mutant Htt protein aggregation in HD mice (Zuleta et al. 2012). These findings again suggest that an optimal level of XBP1s expression is essential to promote mutant Htt proper folding and prevent aggregation. In the SOD1 ${ }^{\text {G93A }}$ transgenic ALS mouse model, ER stress and $\mathrm{XBP} 1 \mathrm{~s}$ induction are observed. XBP1 deficiency in motor neurons of SOD1 ${ }^{\mathrm{G} 93 \mathrm{~A}}$ mice also increases autophagy to clear mutant SOD1 aggregates, suggesting that XBP1s may contribute to ALS pathogenesis (Hetz et al. 2009). Therefore, XBP1s has protective or detrimental effects on neurodegeneration, although the exact mechanism remains to be elucidated (Hetz and Saxena 2017).

Cancer Elevated XBP1s expression is observed in many human tumors, including breast cancer (Davies et al. 2008; Chen et al. 2014), pancreatic adenocarcinomas (Romero-Ramirez et al. 2009), multiple myeloma (Carrasco et al. 2007), chronic lymphocytic leukemia (CLL) (Krysov et al. 2014), and plasma cell malignancy (Maestre et al. 2009 ), suggesting that $X b p 1$ is a proto-oncogene. Consistently, myeloma patients with higher amounts of XBP1s have a poorer overall survival (Bagratuni et al. 2010), and the growth of $X b p 1$-deficient tumor cells is impaired in xenograft models (Romero-Ramirez et al. 2004). XBP1s 
also promotes tumorigenesis by assembling a transcription complex with HIFla to transactivate target genes (Chen et al. 2014) and up-regulating Snail expression to induce epithelial-to-mesenchymal transition (EMT) (Li et al. 2015). XBP1s in tumor-associated dendritic cells promotes ovarian cancer by inhibiting anti-tumor immunity through abnormal lipid accumulation in tumor-associated dendritic cells (Cubillos-Ruiz et al. 2015). In contrast, Xbp1-deficient IECs exhibit increased turnover through NFkB-dependent activation of STAT3, promoting colitisassociated cancer and spontaneous adenomatous polyposis coli (APC)-related tumors in mice (Niederreiter et al. 2013), suggesting that XBP1 might act as a tumor suppressor in the intestine.

As the most ancient UPR TF, XBP1 has a critical role in both physiological and pathological states. The activity of $\mathrm{XBP} 1 \mathrm{~s}$ is affected by either ER stress or other stimuli such as the insulin signaling pathway (Park et al. 2010b; Winnay et al. 2010) or activation of pattern recognition receptors (Martinon et al. 2010; Qiu et al. 2013). This observation implies that this ancient TF might act as a nexus for environmental stimuli besides ER stress. This new concept remains to be elucidated.

\section{Additional TFs}

Several additional TFs are regulated by ER stress and the UPR through transcriptional, translational, or post-translational controls.

ATF5 ATF4 activates transcription of ATF5 (Zhou et al. 2008), which was first cloned as a factor in developing sensory neurons of the olfactory epithelium (Hansen et al. 2002). ATF5 inhibits differentiation of neuroprogenitor cells into neurons (Angelastro et al. 2003) and astrocytes (Angelastro et al. 2005) and of oligodendrocyte precursors into oligodendrocytes (Mason et al. 2005). In contrast, Atf5 $5^{-1-}$ mice exhibit massive reduction in mature olfactory sensory neurons (OSNs), and ectopic expression of ATF5 in neural progenitor cells induces expression of multiple OSN-specific genes, suggesting that ATF5 promotes OSN differentiation (Wang et al. 2012d). ATF5 also promotes survival of malignant cells by stimulating expression of anti-apoptotic B-cell leukemia-2 (BCL2) and myeloid cell leukemia sequence-1 (MCL1), a BCL2 family member (Sheng et al. 2010; Dluzen et al. 2011), indicating a prosurvival role in cancer. In addition, polymorphisms located in the promoter region impact ATF5 expression. Increased ATF5 expression induces asparagine synthetase in acute lymphoblastic leukemia and reduces therapeutic treatment with L-asparaginase (Rousseau et al. 2011). ATF5 can promote inflammatory responses upon ER stress in $\beta$ cells by increasing transcription of thioredoxin-interacting protein (TXNIP) to activate the NLRP3 inflammasome to produce IL-1 $\beta$ (Oslowski et al. 2012).

$N F-\kappa B$ Many studies support the notion that ER stress stimulates inflammatory responses though activation of NK- $\kappa$ B. Various ER stress-inducing agents increase the DNA-binding activity of NF- $\kappa \mathrm{B}$ as well as downstream tar- get gene expression (Pahl and Baeuerle 1995). ER stress is proposed to activate NF- $\mathrm{KB}$ through several mechanisms. ER stress-induced NF- $\mathrm{KB}$ activation is impaired in Ire $1 a$ knockdown cells and Ire $1 a^{-/-}$cells due to loss of an IRE $1 \alpha$ and IкB kinase complex (Hu et al. 2006). In addition, genetic and pharmacological inhibition of ATF6a attenuates NF- $\kappa \mathrm{B}$ activation, suggesting a stimulatory role for ATF6 $\alpha$ in NF- $\kappa$ B signaling (Yamazaki et al. 2009). eIF2 $\alpha$ phosphorylation also activates NF- $\kappa B$ by inhibiting the synthesis of the short-lived inhibitor of NF- $\kappa B, \quad \mathrm{I} \kappa \mathrm{B} \alpha$ (Deng et al. 2002; Jiang et al. 2003). It is essential to provide definitive evidence for a biochemical link between ER stress sensor (IRE1 $\alpha$, PERK, and ATF6a) activation and subsequent downstream inflammatory responses.

In contrast, chronic ER stress inhibits NF- $\mathrm{KB}$ activity (Hayakawa et al. 2009). Furthermore, preconditioning with ER stress markedly inhibits expression of NF-kB target cytokines through up-regulation of $\mathrm{C} / \mathrm{EBP} \beta$ (Du et al. 2009). This phenomenon is mediated by up-regulation of the ubiquitin-editing enzyme A20 (also known as TNFAIP3) upon ER stress, which is an endogenous negative regulator of NF- $\kappa B$ (Nakajima et al. 2010).

CREBH CREBH, encoded by CREB3L3, is a hepatocytespecific TF that was originally identified as a central regulator of the acute phase response (Zhang et al. 2006). As a mediator of inflammatory responses in the liver, CREBH controls hepatic lipid metabolism under metabolic stress conditions (Zhang et al. 2012). Inflammatory cytokines induce transcription of CREBH, and ER stress stimulates its cleavage and activation by S1P and S2P. CREBH promotes expression of genes encoding functions in de novo lipogenesis, TG and cholesterol biosynthesis, fatty acid elongation and oxidation, lipolysis, and lipid transport. In addition, CREBH activates expression of Fsp27, a lipid droplet-associated protein (Xu et al. 2015). Consistently, forced expression of CREBH in the liver causes hepatic lipid accumulation, although TG levels in the blood decrease (Zhang et al. 2012; Xu et al. 2015). In addition, $\mathrm{CREBH}$ promotes expression of lipoprotein lipase (Lpl) coactivators apolipoprotein C2 (Apoc2), Apoa4, and Apoa5 and concurrently down-regulates $\mathrm{Lpl}$ inhibitor Apoc3 (Lee et al. 2011b). As a result, Crebl3 ${ }^{-/-}$mice display hypertriglyceridemia due to inefficient TG clearance. Furthermore, multiple nonsynonymous mutations in $C R E B 3 L 3$ are associated with extreme hypertriglyceridemia, suggesting a pivotal role of CREBH in human TG metabolism (Lee et al. 2011b). In addition to lipid metabolism, CREBH promotes hepatic gluconeogenesis by inducing expression of gluconeogenic enzyme in a CRTC2-dependent manner (Lee et al. 2010b). Consistently, knockdown of CREBH improves fasting hyperglycemia in diabetic $d b / d b$ mice, suggesting that CREBH is a critical regulator for hepatic gluconeogenesis.

\section{Integrated response of UPR TFs}

Here we described the function of each UPR-associated TF in multiple cellular pathways and associated diseases. 
However, it is also important to consider that bZIP TFs bind DNA as either homodimers or heterodimers. Their partners could be other UPR TFs or different TFs with no function in the UPR. For example, expression of ATF4 target genes is enhanced when it heterodimerizes with CHOP upon ER stress (Han et al. 2013a). XBP1u translated from mammalian unspliced XBP1 mRNA acts as negative regulator by heterodimerizing with XBP1s to promote its degradation (Yoshida et al. 2006). In addition, ATF6 $\alpha / \mathrm{XBP} 1$ and CREBH/ATF6 $\alpha$ heterodimers possess greater transcriptional activity than either respective homodimer (Zhang et al. 2006; Yamamoto et al. 2007).

The UPR TFs also form heterodimers with the other TFs with no or little function in the UPR. ATF4 forms heterodimers with nuclear factor-like 2 (NRF2) and C/EBP $\gamma$ upon oxidative stress to activate transcription of antioxidant genes (He et al. 2001; Huggins et al. 2015). Heterodimers of CHOP and C/EBP $\beta$ inhibit adipogenesis (Tang and Lane 2000). In addition, insulin signaling disrupts p85a$\mathrm{p} 85 \beta$ heterodimers so that $\mathrm{p} 85$ can interact with XBP1s to facilitate its nuclear translocation and induce UPR transcription (Park et al. 2010b). These results strongly suggest that combinatorial interactions of TFs may generate diverse responses to different stimuli in different cell types.

\section{Therapeutic implications}

Given the role of UPR-induced TFs across a range of human diseases, there is great interest in pharmacologically modulating their activity to control ER stress-mediated diseases. There are two approaches to modulate TF activity. The first is to develop small molecules that can directly bind and modulate TF function. The second is to modulate effectors upstream of or downstream from the TFs.

TFs are generally considered to be poor drug targets due to the inability of small molecules to block protein-protein and protein-DNA binding interfaces (Imming et al. 2006). Although chemical genomics provides examples of small molecules that can modulate the activity of TFs, until now, few small molecules were reported to directly bind and inhibit TFs. Nevertheless, several studies identified small molecules that modulate the activity or expression UPR TFs. For example, E235 was identified through the screening of small molecules that activate ATF4 expression in human fibrosarcoma HT1080 cells (Sayers et al. 2013). E235 treatment increases the levels of phosphorylated eIF2 $\alpha$ without induction of XBP1 splicing. E235 decreases viability in several mouse and human cell lines, which is abolished by knockdown of ATF4, suggesting that this drug acts specifically on eIF2a/ATF4. Another small molecule, ML291, was developed through a high-throughput screen of the National Institutes of Health Molecular Libraries Small Molecule Repository (MLSMR) (Flaherty et al. 2010). This molecule selectively activates the eIF2a/ATF4 pathway but not the IRE1 $\alpha$ or ATF6a pathway. This molecule induces cell death in a CHOP-dependent manner in a number of cell lines, and there is enthusiastic support to develop this molecule for cancer therapy. A recent study also suggests that modulation of ER stress could be a selective target for cancer cells that undergo EMT (Feng et al. 2014). During EMT, cells secrete more secretory molecules, such as extracellular matrix proteins, which provokes eIF2 $\alpha$ phosphorylation and subsequent ATF4 induction. Thus, cells undergoing EMT are more sensitive to ER stress compared with cells without EMT. This selective toxicity of cells stressed by a harsh environment or protein misfolding offers a selective advantage to using these agents to uniquely destroy tumor cells (Feng et al. 2014).

For XBP1, several small molecules have been developed recently (Obacz et al. 2017). STF-083010 (Papandreou et al. 2011), salicylaldehydes (Volkmann et al. 2011), 4p8C (Cross et al. 2012), compound 3 (Wang et al. 2012b), and quercetin (Wiseman et al. 2010) exert their effect on XBP1 by modulating IRE1a activity. Although XBP1 mRNA is the only splicing substrate for IRE1 $\alpha$, targeting IRE $1 \alpha$ activity might cause unknown adverse effects due to RIDD. In contrast to these molecules, toyocamycin, a nucleoside-type antibiotic analog of adenosine, blocks chemically induced XBP1 splicing as well as XBP1 target gene expression without affecting IRE1 a phosphorylation (Ri et al. 2012). MKC-3946, a salicylaldehydes derivative, inhibits chemically induced XBP1 splicing in multiple myeloma cell lines as well as patient-derived samples without affecting IRE1 $\alpha$ phosphorylation in this context (Mimura et al. 2012). In addition, other small molecules, including MKC9989, OICR464, and OICR573, block XBP1 splicing with minimal effect on IRE1 $\alpha$ kinase activity, suggesting a direct effect on XBP1 (Sanches et al. 2014).

Another approach to modulate UPR TFs is to use small molecules that can inhibit upstream factors. For example, GSK2656157, an ATP-competitive inhibitor of PERK, suppresses eIF2 $\alpha$ phosphorylation and decreases ATF4 and CHOP expression through inhibition of stress-induced PERK autophosphorylation (Atkins et al. 2013). However, the effects of GSK2656157 are not solely dependent on PERK and eIF2a phosphorylation (Krishnamoorthy et al. 2014). Another PERK inhibitor, GSK2606414, gave new insight into how this small molecule can be used in human disease. Prion disease, which is caused by accumulation of misfolded prion protein $(\operatorname{PrP})$ due to prion replication, causes sustained activation of the PERK/eIF2 a pathway (Moreno et al. 2012). Oral treatment with GSK2606414 prevented UPR-mediated translational attenuation and abrogated development of prion diseases in mice (Moreno et al. 2013). Importantly, this molecule can penetrate the blood-brain barrier, showing therapeutic potential for brain disease.

Although there have been advances in the development of small molecules to target UPR TFs for therapeutic application, there must be some cautionary considerations for this approach. First, the expression levels of TFs need to be properly regulated at the appropriate level. For example, the absence of ATF6a causes liver steatosis upon ER stress (Wu et al. 2007; Rutkowski et al. 2008; Yamamoto et al. 2010), whereas overexpression of the active form of ATF6a in zebrafish livers causes fatty liver due to lipid accumulation (Howarth et al. 2014). There appears to be an 
optimum of expression versus toxicity. This is an essential feature that needs further investigation. Spatial differences in expression are another aspect that needs to be considered. Since the expression of some proteins is essential for some cells, such as PERK in pancreatic $\beta$ cells, the impact of inhibiting their expression in other tissues needs further investigation. Additionally, expression of ATF4 in the hypothalamus induces insulin resistance, whereas ATF4 expression in muscle protects against diet-induced insulin resistance, suggesting that even the same TF exerts responses depending on when and where it is expressed. This emphasizes the requirement to target selective UPR agonist/antagonist pathways in selective cell types. If these two technologies are blended together, it will be beneficial to modulate UPR signaling to ameliorate disease progression.

Alternatively, it can be envisioned that targeting UPR signaling may be very selective to those cells that experience ER stress; i.e., virally infected cells, cells exposed to toxic compounds, and transformed cells. Thus, there is tremendous potential to selectively target "stressed" cells versus normal cells.

\section{Perspectives}

The UPR is a set of highly conserved signal transduction pathways activated when ER homeostasis is disturbed, referred to as ER stress. The ultimate step in the UPR involves activation of a set of bZIP-containing TFs that coordinate adaptive or cell death responses. Numerous signal transduction events and TFs are known that signal the UPR, although their significance and roles in physiology and pathophysiology remain largely unknown. Although the primary role of these TFs is to restore ER homeostasis, new lines of evidence suggest that they provide functions in other physiological or pathological processes, including immune responses, cancer development, and insulin signaling. The diverse function of each TF activated by the UPR might be due to their characteristic to form heterodimers with different partners at different times or in response to different stimuli. Thus, it is essential to identify the process by which these TFs network to affect or interact with other TFs. Nevertheless, targeting the TFs is an attractive approach to treat ER stress-mediated human disease. However, it is not known how these TFs function in the absence of ER stress, but, based on the significant phenotypes observed upon their deletion, it is likely that they function in cell-typespecific networks in many aspects of cell physiology. Identifying the role of TFs associated with ER stress and their role in the absence of ER stress will provide novel insights for future investigations to characterize the mechanism and functionality toward development of therapeutic applications for many disease states.

\section{Acknowledgments}

We apologize to those whom we were unable to reference due to space limitations. R.J.K. is supported by National Institutes of
Health/National Cancer Institute grants R37DK042394, R01DK103185, R24DK110973, and R01CA198103. J.H. is supported by the Basic Science Research Program through the National Research Foundation of Korea (NRF) funded by the Ministry of Education (NRF-2015R1D1A1A01058846 and NRF2017M3A9C6033069).

\section{References}

Abdelrahim M, Newman K, Vanderlaag K, Samudio I, Safe S. 2006. 3,3'-diindolylmethane (DIM) and its derivatives induce apoptosis in pancreatic cancer cells through endoplasmic reticulum stress-dependent upregulation of DR5. Carcinogenesis 27: 717-728.

Adolph TE, Tomczak MF, Niederreiter L, Ko HJ, Bock J, Martinez-Naves E, Glickman JN, Tschurtschenthaler M, Hartwig J, Hosomi S, et al. 2013. Paneth cells as a site of origin for intestinal inflammation. Nature 503: 272-276.

Aime P, Sun X, Zareen N, Rao A, Berman Z, Volpicelli-Daley L, Bernd P, Crary JF, Levy OA, Greene LA. 2015. Trib3 is elevated in Parkinson's disease and mediates death in Parkinson's disease models. J Neurosci 35: 10731-10749.

Ali MM, Bagratuni T, Davenport EL, Nowak PR, Silva-Santisteban MC, Hardcastle A, McAndrews C, Rowlands MG, Morgan G), Aherne W, et al. 2011. Structure of the Ire1 autophosphorylation complex and implications for the unfolded protein response. EMBO J 30: 894-905.

Allagnat F, Christulia F, Ortis F, Pirot P, Lortz S, Lenzen S, Eizirik DL, Cardozo AK. 2010. Sustained production of spliced X-box binding protein 1 (XBP1) induces pancreatic $\beta$ cell dysfunction and apoptosis. Diabetologia 53: 1120-1130.

Allagnat F, Fukaya M, Nogueira TC, Delaroche D, Welsh N, Marselli L, Marchetti P, Haefliger JA, Eizirik DL, Cardozo AK. 2012. C/EBP homologous protein contributes to cytokine-induced pro-inflammatory responses and apoptosis in $\beta$-cells. Cell Death Differ 19: 1836-1846.

Allen-Jennings AE, Hartman MG, Kociba GJ, Hai T. 2002. The roles of ATF3 in liver dysfunction and the regulation of phosphoenolpyruvate carboxykinase gene expression. J Biol Chem 277: 20020-20025.

Ameri K, Lewis CE, Raida M, Sowter H, Hai T, Harris AL. 2004. Anoxic induction of ATF-4 through HIF-1-independent pathways of protein stabilization in human cancer cells. Blood 103: $1876-1882$.

Angelastro JM, Ignatova TN, Kukekov VG, Steindler DA, Stengren GB, Mendelsohn C, Greene LA. 2003. Regulated expression of ATF5 is required for the progression of neural progenitor cells to neurons. J Neurosci 23: 4590-4600.

Angelastro JM, Mason JL, Ignatova TN, Kukekov VG, Stengren GB, Goldman JE, Greene LA. 2005. Downregulation of activating transcription factor 5 is required for differentiation of neural progenitor cells into astrocytes. I Neurosci 25: 3889-3899.

Ansar M, Santos-Cortez RL, Saqib MA, Zulfiqar F, Lee K, Ashraf NM, Ullah E, Wang X, Sajid S, Khan FS, et al. 2015. Mutation of ATF6 causes autosomal recessive achromatopsia. Hum Genet 134: 941-950.

Arai M, Kondoh N, Imazeki N, Hada A, Hatsuse K, Kimura F, Matsubara O, Mori K, Wakatsuki T, Yamamoto M. 2006. Transformation-associated gene regulation by ATF6a during hepatocarcinogenesis. FEBS Lett 580: 184-190.

Atkins C, Liu Q, Minthorn E, Zhang SY, Figueroa DJ, Moss K, Stanley TB, Sanders B, Goetz A, Gaul N, et al. 2013. Characterization of a novel PERK kinase inhibitor with antitumor and antiangiogenic activity. Cancer Res 73: 1993-2002. 
Back SH, Scheuner D, Han J, Song B, Ribick M, Wang J, Gildersleeve RD, Pennathur S, Kaufman RJ. 2009. Translation attenuation through eIF2 $\alpha$ phosphorylation prevents oxidative stress and maintains the differentiated state in $\beta$ cells. Cell Metab 10: 13-26.

Bagratuni T, Wu P, Gonzalez de Castro D, Davenport EL, Dickens NJ, Walker BA, Boyd K, Johnson DC, Gregory W, Morgan GJ, et al. 2010. XBP1s levels are implicated in the biology and outcome of myeloma mediating different clinical outcomes to thalidomide-based treatments. Blood 116: 250-253.

Bai Y, Hassler J, Ziyar A, Li P, Wright Z, Menon R, Omenn GS, Cavalcoli JD, Kaufman RJ, Sartor MA. 2014. Novel bioinformatics method for identification of genome-wide non-canonical spliced regions using RNA-seq data. PLoS One 9: e100864.

Baleriola J, Walker CA, Jean YY, Crary JF, Troy CM, Nagy PL, Hengst U. 2014. Axonally synthesized ATF4 transmits a neurodegenerative signal across brain regions. Cell 158: 1159-1172.

Barbosa C, Peixeiro I, Romao L. 2013. Gene expression regulation by upstream open reading frames and human disease. PLOS Genet 9: e1003529.

Batchvarova N, Wang XZ, Ron D. 1995. Inhibition of adipogenesis by the stress-induced protein CHOP (Gadd153). EMBO J 14: 4654-4661.

Bernales S, Papa FR, Walter P. 2006. Intracellular signaling by the unfolded protein response. Annu Rev Cell Dev Biol 22: 487-508.

Bertolotti A, Zhang Y, Hendershot LM, Harding HP, Ron D. 2000. Dynamic interaction of $\mathrm{BiP}$ and ER stress transducers in the unfolded-protein response. Nat Cell Biol 2: 326-332.

Bettigole SE, Lis R, Adoro S, Lee AH, Spencer LA, Weller PF, Glimcher LH. 2015. The transcription factor XBP1 is selectively required for eosinophil differentiation. Nat Immunol 16: 829-837.

Bi M, Naczki C, Koritzinsky M, Fels D, Blais J, Hu N, Harding H, Novoa I, Varia M, Raleigh J, et al. 2005. ER stress-regulated translation increases tolerance to extreme hypoxia and promotes tumor growth. EMBO I 24: 3470-3481.

Boespflug ND, Kumar S, McAlees JW, Phelan JD, Grimes HL, Hoebe K, Hai T, Filippi MD, Karp CL. 2014. ATF3 is a novel regulator of mouse neutrophil migration. Blood 123: 2084-2093.

Bottone FG Jr, Martinez JM, Collins JB, Afshari CA, Eling TE. 2003. Gene modulation by the cyclooxygenase inhibitor, sulindac sulfide, in human colorectal carcinoma cells: possible link to apoptosis. J Biol Chem 278: 25790-25801.

Bouman L, Schlierf A, Lutz AK, Shan J, Deinlein A, Kast J, Galehdar Z, Palmisano V, Patenge N, Berg D, et al. 2011. Parkin is transcriptionally regulated by ATF4: evidence for an interconnection between mitochondrial stress and ER stress. Cell Death Differ 18: 769-782.

Calfon M, Zeng H, Urano F, Till JH, Hubbard SR, Harding HP, Clark SG, Ron D. 2002. IRE1 couples endoplasmic reticulum load to secretory capacity by processing the XBP-1 mRNA. Nature 415: 92-96.

Cao H, Yu S, Yao Z, Galson DL, Jiang Y, Zhang X, Fan J, Lu B, Guan Y, Luo M, et al. 2010. Activating transcription factor 4 regulates osteoclast differentiation in mice. $J$ Clin Invest 120: $2755-2766$.

Carrasco DR, Sukhdeo K, Protopopova M, Sinha R, Enos M, Carrasco DE, Zheng $M$, Mani $M$, Henderson J, Pinkus GS, et al. 2007. The differentiation and stress response factor XBP-1 drives multiple myeloma pathogenesis. Cancer Cell 11: 349-360.
Casas-Tinto S, Zhang Y, Sanchez-Garcia J, Gomez-Velazquez M, Rincon-Limas DE, Fernandez-Funez P. 2011. The ER stress factor XBP1s prevents amyloid- $\beta$ neurotoxicity. Hum Mol Genet 20: 2144-2160.

Caselli E, Benedetti S, Grigolato J, Caruso A, Di Luca D. 2012. Activating transcription factor 4 (ATF4) is upregulated by human herpesvirus 8 infection, increases virus replication and promotes proangiogenic properties. Arch Virol 157: 63-74.

Chen X, Shen J, Prywes R. 2002. The luminal domain of ATF6 senses endoplasmic reticulum (ER) stress and causes translocation of ATF6 from the ER to the Golgi. J Biol Chem 277: 13045-13052.

Chen Y, Wang JJ, Li J, Hosoya KI, Ratan R, Townes T, Zhang SX. 2012. Activating transcription factor 4 mediates hyperglycaemia-induced endothelial inflammation and retinal vascular leakage through activation of STAT3 in a mouse model of type 1 diabetes. Diabetologia 55: 2533-2545.

Chen X, Iliopoulos D, Zhang Q, Tang Q, Greenblatt MB, Hatziapostolou M, Lim E, Tam WL, Ni M, Chen Y, et al. 2014. XBP1 promotes triple-negative breast cancer by controlling the HIFla pathway. Nature 508: 103-107.

Chiang WC, Chan P, Wissinger B, Vincent A, Skorczyk-Werner A, Krawczynski MR, Kaufman RJ, Tsang SH, Heon E, Kohl S, et al. 2017. Achromatopsia mutations target sequential steps of ATF6 activation. Proc Natl Acad Sci 114: 400-405.

Credle JJ, Forcelli PA, Delannoy M, Oaks AW, Permaul E, Berry DL, Duka V, Wills J, Sidhu A. 2015. a-Synuclein-mediated inhibition of ATF6 processing into COPII vesicles disrupts UPR signaling in Parkinson's disease. Neurobiol Dis 76: 112-125.

Cross BC, Bond PJ, Sadowski PG, Jha BK, Zak J, Goodman JM, Silverman RH, Neubert TA, Baxendale IR, Ron D, et al. 2012. The molecular basis for selective inhibition of unconventional mRNA splicing by an IRE1-binding small molecule. Proc Natl Acad Sci 109: E869-E878.

Cubillos-Ruiz JR, Silberman PC, Rutkowski MR, Chopra S, Perales-Puchalt A, Song M, Zhang S, Bettigole SE, Gupta D, Holcomb K, et al. 2015. ER stress sensor XBP1 controls anti-tumor immunity by disrupting dendritic cell homeostasis. Cell 161: 1527-1538.

Cucinotta M, Visalli M, Aguennouz M, Valenti A, Loddo S, Altucci L, Teti D. 2008. Regulation of interleukin-8 gene at a distinct site of its promoter by CCAAT enhancer-binding protein homologous protein in prostaglandin E2-treated human T cells. J Biol Chem 283: 29760-29769.

Cui H, Guo M, Xu D, Ding ZC, Zhou G, Ding HF, Zhang J, Tang Y, Yan C. 2015. The stress-responsive gene ATF3 regulates the histone acetyltransferase Tip60. Nat Commun 6: 6752.

Dalton LE, Clarke HJ, Knight J, Lawson MH, Wason J, Lomas DA, Howat WJ, Rintoul RC, Rassl DM, Marciniak SJ. 2013. The endoplasmic reticulum stress marker $\mathrm{CHOP}$ predicts survival in malignant mesothelioma. Br J Cancer 108: 1340-1347.

Davies MP, Barraclough DL, Stewart C, Joyce KA, Eccles RM, Barraclough R, Rudland PS, Sibson DR. 2008. Expression and splicing of the unfolded protein response gene XBP-1 are significantly associated with clinical outcome of endocrinetreated breast cancer. Int J Cancer 123: 85-88.

De Nardo D, Labzin LI, Kono H, Seki R, Schmidt SV, Beyer M, Xu D, Zimmer S, Lahrmann C, Schildberg FA, et al. 2014. Highdensity lipoprotein mediates anti-inflammatory reprogramming of macrophages via the transcriptional regulator ATF3. Nat Immunol 15: 152-160.

Deng J, Harding HP, Raught B, Gingras AC, Berlanga JJ, Scheuner D, Kaufman RJ, Ron D, Sonenberg N. 2002. Activation of GCN2 in UV-irradiated cells inhibits translation. Curr Biol 12: $1279-1286$. 
Deng I, Lu PD, Zhang Y, Scheuner D, Kaufman RJ, Sonenberg N, Harding HP, Ron D. 2004. Translational repression mediates activation of nuclear factor $\mathrm{\kappa B}$ by phosphorylated translation initiation factor 2. Mol Cell Biol 24: 10161-10168.

Dey S, Sayers CM, Verginadis II, Lehman SL, Cheng Y, Cerniglia GJ, Tuttle SW, Feldman MD, Zhang PJ, Fuchs SY, et al. 2015. ATF4-dependent induction of heme oxygenase 1 prevents anoikis and promotes metastasis. I Clin Invest 125: 2592-2608.

DeZwaan-McCabe D, Riordan JD, Arensdorf AM, Icardi MS, Dupuy AJ, Rutkowski DT. 2013. The stress-regulated transcription factor CHOP promotes hepatic inflammatory gene expression, fibrosis, and oncogenesis. PLoS Genet 9: e1003937.

Dluzen D, Li G, Tacelosky D, Moreau M, Liu DX. 2011. BCL-2 is a downstream target of ATF5 that mediates the prosurvival function of ATF5 in a cell type-dependent manner. I Biol Chem 286: 7705-7713.

D'Osualdo A, Anania VG, Yu K, Lill JR, Kaufman RJ, Matsuzawa S, Reed JC. 2015. Transcription factor ATF4 induces NLRP1 inflammasome expression during endoplasmic reticulum stress. PLoS One 10: e0130635.

Du S, Hiramatsu N, Hayakawa K, Kasai A, Okamura M, Huang T, Yao J, Takeda M, Araki I, Sawada N, et al. 2009. Suppression of NF- $\kappa$ B by cyclosporin a and tacrolimus (FK506) via induction of the C/EBP family: implication for unfolded protein response. I Immunol 182: 7201-7211.

Edagawa M, Kawauchi J, Hirata M, Goshima H, Inoue M, Okamoto T, Murakami A, Maehara Y, Kitajima S. 2014. Role of activating transcription factor 3 (ATF3) in endoplasmic reticulum (ER) stress-induced sensitization of p53-deficient human colon cancer cells to tumor necrosis factor (TNF)-related apoptosis-inducing ligand (TRAIL)-mediated apoptosis through up-regulation of death receptor 5 (DR5) by zerumbone and celecoxib. J Biol Chem 289: 21544-21561.

Endo M, Mori M, Akira S, Gotoh T. 2006. C/EBP homologous protein (CHOP) is crucial for the induction of caspase- 11 and the pathogenesis of lipopolysaccharide-induced inflammation. I Immunol 176: 6245-6253.

Engin F, Yermalovich A, Nguyen T, Hummasti S, Fu W, Eizirik DL, Mathis D, Hotamisligil GS. 2013. Restoration of the unfolded protein response in pancreatic $\beta$ cells protects mice against type 1 diabetes. Sci Trans1 Med 5: 211 ra156.

Fei Y, Xiao L, Hurley MM. 2010. Fibroblast growth factor 2 positively regulates expression of activating transcription factor 4 in osteoblasts. Biochem Biophys Res Commun 391: 335-339.

Feng YX, Sokol ES, Del Vecchio CA, Sanduja S, Claessen JH, Proia TA, Jin DX, Reinhardt F, Ploegh HL, Wang Q, et al. 2014. Epithelial-to-mesenchymal transition activates PERK-eIF2 $\alpha$ and sensitizes cells to endoplasmic reticulum stress. Cancer Discov 4: 702-715.

Flaherty DP, Golden JE, Liu C, Hedrick M, Gosalia P, Li Y, Milewski M, Sugarman E, Suyama E, Nguyen K, et al. 2010. Selective small molecule activator of the apoptotic arm of the UPR. In Probe reports from the NIH Molecular Libraries Program. National Center for Biotechnology Information, Bethesda, MD. https://www.ncbi.nlm.nih.gov/books/NBK133431.

Flaherty DP, Miller JR, Garshott DM, Hedrick M, Gosalia P, Li Y, Milewski M, Sugarman E, Vasile S, Salaniwal S, et al. 2014. Discovery of sulfonamidebenzamides as selective apoptotic CHOP pathway activators of the unfolded protein response. ACS Med Chem Lett 5: 1278-1283.

Gargiulo G, Cesaroni M, Serresi M, de Vries N, Hulsman D, Bruggeman SW, Lancini C, van Lohuizen M. 2013. In vivo RNAi screen for BMI1 targets identifies TGF- $\beta /$ BMP-ER stress path- ways as key regulators of neural- and malignant glioma-stem cell homeostasis. Cancer Cell 23: 660-676.

Gilchrist M, Thorsson V, Li B, Rust AG, Korb M, Roach JC, Kennedy K, Hai T, Bolouri H, Aderem A. 2006. Systems biology approaches identify ATF3 as a negative regulator of Toll-like receptor 4. Nature 441: 173-178.

Gonzalez-Rodriguez A, Mayoral R, Agra N, Valdecantos MP, Pardo V, Miquilena-Colina ME, Vargas-Castrillon J, Lo Iacono O, Corazzari M, Fimia GM, et al. 2014. Impaired autophagic flux is associated with increased endoplasmic reticulum stress during the development of NAFLD. Cell Death Dis 5: e1179.

Goodall JC, Wu C, Zhang Y, McNeill L, Ellis L, Saudek V, Gaston JS. 2010. Endoplasmic reticulum stress-induced transcription factor, CHOP, is crucial for dendritic cell IL-23 expression. Proc Natl Acad Sci 107: 17698-17703.

Guenova E, Skabytska Y, Hoetzenecker W, Weindl G, Sauer K, Tham M, Kim KW, Park JH, Seo JH, Ignatova D, et al. 2015. IL-4 abrogates $\mathrm{T}(\mathrm{H}) 17$ cell-mediated inflammation by selective silencing of IL-23 in antigen-presenting cells. Proc NatI Acad Sci 112: 2163-2168.

Gutierrez T, Simmen T. 2014. Endoplasmic reticulum chaperones and oxidoreductases: critical regulators of tumor cell survival and immunorecognition. Front Oncol 4: 291.

Han AP, Yu C, Lu L, Fujiwara Y, Browne C, Chin G, Fleming M, Leboulch P, Orkin SH, Chen JJ. 2001. Heme-regulated eIF2 $a$ kinase (HRI) is required for translational regulation and survival of erythroid precursors in iron deficiency. EMBO I 20: 6909-6918.

Han D, Lerner AG, Vande Walle L, Upton JP, Xu W, Hagen A, Backes BJ, Oakes SA, Papa FR. 2009. IRE1a kinase activation modes control alternate endoribonuclease outputs to determine divergent cell fates. Cell 138: 562-575.

Han J, Back SH, Hur J, Lin YH, Gildersleeve R, Shan J, Yuan CL, Krokowski D, Wang S, Hatzoglou M, et al. 2013a. ER-stressinduced transcriptional regulation increases protein synthesis leading to cell death. Nat Cell Biol 15: 481-490.

Han J, Murthy R, Wood B, Song B, Wang S, Sun B, Malhi H, Kaufman RJ. 2013b. ER stress signalling through eIF2 $\alpha$ and CHOP, but not IRE $1 \alpha$, attenuates adipogenesis in mice. Diabetologia 56: 911-924.

Han J, Song B, Kim J, Kodali VK, Pottekat A, Wang M, Hassler J, Wang S, Pennathur S, Back SH, et al. 2015. Antioxidants complement the requirement for protein chaperone function to maintain $\beta$-cell function and glucose homeostasis. Diabetes 64: 2892-2904.

Hansen MB, Mitchelmore C, Kjaerulff KM, Rasmussen TE, Pedersen KM, Jensen NA. 2002. Mouse Atf5: molecular cloning of two novel mRNAs, genomic organization, and odorant sensory neuron localization. Genomics 80: 344-350.

Harding HP, Zhang Y, Ron D. 1999. Protein translation and folding are coupled by an endoplasmic-reticulum-resident kinase. Nature 397: 271-274.

Harding HP, Novoa I, Zhang Y, Zeng H, Wek R, Schapira M, Ron D. 2000. Regulated translation initiation controls stress-induced gene expression in mammalian cells. Mol Cell 6: $1099-1108$.

Hashida K, Kitao Y, Sudo H, Awa Y, Maeda S, Mori K, Takahashi $\mathrm{R}$, Iinuma M, Hori O. 2012. ATF6 $a$ promotes astroglial activation and neuronal survival in a chronic mouse model of Parkinson's disease. PLoS One 7: e47950.

Hassler JR, Scheuner DL, Wang S, Han J, Kodali VK, Li P, Nguyen J, George JS, Davis C, Wu SP, et al. 2015. The IRE1a/XBP1s pathway is essential for the glucose response and protection of $\beta$ cells. PLOS Biol 13: e1002277. 
Hattori T, Ohoka N, Hayashi H, Onozaki K. 2003. C/EBP homologous protein (CHOP) up-regulates IL-6 transcription by trapping negative regulating NF-IL6 isoform. FEBS Lett 541: 33-39.

Hayakawa K, Hiramatsu N, Okamura M, Yamazaki H, Nakajima S, Yao J, Paton AW, Paton JC, Kitamura M. 2009. Acquisition of anergy to proinflammatory cytokines in nonimmune cells through endoplasmic reticulum stress response: a mechanism for subsidence of inflammation. J Immunol 182: 1182-1191.

Haze K, Yoshida H, Yanagi H, Yura T, Mori K. 1999. Mammalian transcription factor ATF6 is synthesized as a transmembrane protein and activated by proteolysis in response to endoplasmic reticulum stress. Mol Biol Cell 10: 3787-3799.

He CH, Gong P, Hu B, Stewart D, Choi ME, Choi AM, Alam J. 2001. Identification of activating transcription factor 4 (ATF4) as an Nrf2-interacting protein. Implication for heme oxygenase-1 gene regulation. J Biol Chem 276: 20858-20865.

Hettmann T, Barton K, Leiden JM. 2000. Microphthalmia due to p53-mediated apoptosis of anterior lens epithelial cells in mice lacking the CREB-2 transcription factor. Dev Biol 222: 110-123.

Hetz C, Saxena S. 2017. ER stress and the unfolded protein response in neurodegeneration. Nat Rev Neurol 13: 477-491.

Hetz C, Thielen P, Matus S, Nassif M, Court F, Kiffin R, Martinez G, Cuervo AM, Brown RH, Glimcher LH. 2009. XBP-1 deficiency in the nervous system protects against amyotrophic lateral sclerosis by increasing autophagy. Genes Dev 23: 2294-2306.

Hinnebusch AG, Ivanov IP, Sonenberg N. 2016. Translational control by 5 '-untranslated regions of eukaryotic mRNAs. Science 352: 1413-1416.

Hoetzenecker W, Echtenacher B, Guenova E, Hoetzenecker K, Woelbing F, Bruck J, Teske A, Valtcheva N, Fuchs K, Kneilling M, et al. 2012. ROS-induced ATF3 causes susceptibility to secondary infections during sepsis-associated immunosuppression. Nat Med 18: 128-134.

Holtz WA, Turetzky JM, O'Malley KL. 2005. Microarray expression profiling identifies early signaling transcripts associated with 6-OHDA-induced dopaminergic cell death. Antioxid Redox Signal 7: 639-648.

Horiguchi M, Koyanagi S, Okamoto A, Suzuki SO, Matsunaga N, Ohdo S. 2012. Stress-regulated transcription factor ATF4 promotes neoplastic transformation by suppressing expression of the INK4a/ARF cell senescence factors. Cancer Res 72: 395-401.

Hotamisligil GS. 2010. Endoplasmic reticulum stress and the inflammatory basis of metabolic disease. Cell 140: 900-917.

Howarth DL, Lindtner C, Vacaru AM, Sachidanandam R, Tsedensodnom O, Vasilkova T, Buettner C, Sadler KC. 2014. Activating transcription factor 6 is necessary and sufficient for alcoholic fatty liver disease in zebrafish. PLOS Genet 10: e1004335.

Hu P, Han Z, Couvillon AD, Kaufman RJ, Exton JH. 2006. Autocrine tumor necrosis factor a links endoplasmic reticulum stress to the membrane death receptor pathway through IRE1 $\mathrm{a}$-mediated NF- $\mathrm{kB}$ activation and down-regulation of TRAF2 expression. Mol Cell Biol 26: 3071-3084.

Hu J, Dang N, Menu E, De Bruyne E, Xu D, Van Camp B, Van Valckenborgh E, Vanderkerken K. 2012. Activation of ATF4 mediates unwanted Mcl-1 accumulation by proteasome inhibition. Blood 119: 826-837.

Huang H, Jing G, Wang JJ, Sheibani N, Zhang SX. 2015. ATF4 is a novel regulator of MCP-1 in microvascular endothelial cells. J Inflamm 12: 31.
Huber AL, Lebeau J, Guillaumot P, Petrilli V, Malek M, Chilloux J, Fauvet F, Payen L, Kfoury A, Renno T, et al. 2013. p58(IPK)mediated attenuation of the proapoptotic PERK-CHOP pathway allows malignant progression upon low glucose. Mol Cell 49: 1049-1059.

Huggins CJ, Mayekar MK, Martin N, Saylor KL, Gonit M, Jailwala P, Kasoji M, Haines DC, Quinones OA, Johnson PF. 2015. C/ $\mathrm{EBP} \gamma$ is a critical regulator of cellular stress response networks through heterodimerization with ATF4. Mol Cell Biol 36: 693-713.

Imming P, Sinning C, Meyer A. 2006. Drugs, their targets and the nature and number of drug targets. Nat Rev Drug Discov 5: $821-834$.

Ishizawa J, Kojima $\mathrm{K}$, Chachad D, Ruvolo $\mathrm{P}$, Ruvolo $\mathrm{V}$, Jacamo RO, Borthakur G, Mu H, Zeng Z, Tabe Y, et al. 2016. ATF4 induction through an atypical integrated stress response to ONC201 triggers p53-independent apoptosis in hematological malignancies. Sci Signal 9: ra17.

Iwakoshi NN, Lee AH, Vallabhajosyula P, Otipoby KL, Rajewsky K, Glimcher LH. 2003. Plasma cell differentiation and the unfolded protein response intersect at the transcription factor XBP-1. Nat Immunol 4: 321-329.

Iwakoshi NN, Pypaert M, Glimcher LH. 2007. The transcription factor XBP-1 is essential for the development and survival of dendritic cells. J Exp Med 204: 2267-2275.

Iwasaki Y, Suganami T, Hachiya R, Shirakawa I, Kim-Saijo M, Tanaka $M$, Hamaguchi $M$, Takai-Igarashi $T$, Nakai $M$, Miyamoto $\mathrm{Y}$, et al. 2014. Activating transcription factor 4 links metabolic stress to interleukin-6 expression in macrophages. Diabetes 63: 152-161.

Jang MK, Park HJ, Jung MH. 2011. ATF3 represses PDX-1 expression in pancreatic $\beta$-cells. Biochem Biophys Res Commun 412: 385-390.

Janz M, Hummel M, Truss M, Wollert-Wulf B, Mathas S, Johrens K, Hagemeier C, Bommert K, Stein H, Dorken B, et al. 2006. Classical Hodgkin lymphoma is characterized by high constitutive expression of activating transcription factor 3 (ATF3), which promotes viability of Hodgkin/Reed-Sternberg cells. Blood 107: 2536-2539.

Ji C, Mehrian-Shai R, Chan C, Hsu YH, Kaplowitz N. 2005. Role of CHOP in hepatic apoptosis in the murine model of intragastric ethanol feeding. Alcohol Clin Exp Res 29: 1496-1503.

Jiang HY, Wek SA, McGrath BC, Scheuner D, Kaufman RJ, Cavener DR, Wek RC. 2003. Phosphorylation of the a subunit of eukaryotic initiation factor 2 is required for activation of NF- $\mathrm{kB}$ in response to diverse cellular stresses. Mol Cell Biol 23: 5651-5663.

Kaser A, Lee AH, Franke A, Glickman JN, Zeissig S, Tilg H, Nieuwenhuis EE, Higgins DE, Schreiber S, Glimcher LH, et al. 2008. XBP1 links ER stress to intestinal inflammation and confers genetic risk for human inflammatory bowel disease. Cell 134: 743-756.

Kaufman RJ. 1999. Stress signaling from the lumen of the endoplasmic reticulum: coordination of gene transcriptional and translational controls. Genes Dev 13: 1211-1233.

Kaufman RJ. 2002. Orchestrating the unfolded protein response in health and disease. J Clin Invest 110: 1389-1398.

Kaufman RJ. 2004. Regulation of mRNA translation by protein folding in the endoplasmic reticulum. Trends Biochem Sci 29: 152-158.

Khuu CH, Barrozo RM, Hai T, Weinstein SL. 2007. Activating transcription factor 3 (ATF3) represses the expression of CCL4 in murine macrophages. Mol Immunol 44: 1598-1605.

Kikuchi S, Suzuki R, Ohguchi H, Yoshida Y, Lu D, Cottini F, Jakubikova J, Bianchi G, Harada T, Gorgun G, et al. 2015. Class IIa 
HDAC inhibition enhances ER stress-mediated cell death in multiple myeloma. Leukemia 29: 1918-1927.

Kilberg MS, Shan J, Su N. 2009. ATF4-dependent transcription mediates signaling of amino acid limitation. Trends Endocrinol Metab 20: 436-443.

Kim HB, Kong M, Kim TM, Suh YH, Kim WH, Lim JH, Song JH, Jung MH. 2006. NFATc4 and ATF3 negatively regulate adiponectin gene expression in 3T3-L1 adipocytes. Diabetes 55: 1342-1352.

Kim KM, Yu TK, Chu HH, Park HS, Jang KY, Moon WS, Kang MJ, Lee DG, Kim MH, Lee JH, et al. 2012. Expression of ER stress and autophagy-related molecules in human non-small cell lung cancer and premalignant lesions. Int I Cancer 131: E362-E370.

Kim KH, Jeong YT, Oh H, Kim SH, Cho JM, Kim YN, Kim SS, Kim DH, Hur KY, Kim HK, et al. 2013. Autophagy deficiency leads to protection from obesity and insulin resistance by inducing Fgf21 as a mitokine. Nat Med 19: 83-92.

Kode A, Mosialou I, Silva BC, Joshi S, Ferron M, Rached MT, Kousteni S. 2012. FoxO1 protein cooperates with ATF4 protein in osteoblasts to control glucose homeostasis. I Biol Chem 287: 8757-8768.

Kohl S, Zobor D, Chiang W-C, Weisschuh N, Staller J, Menendez IG, Chang S, Beck SC, Garrido MG, Sothilingam V, et al. 2015. Mutations in the unfolded protein response regulator ATF6 cause the cone dysfunction disorder achromatopsia. Nat Genet 47: 757-765.

Kondo S, Murakami T, Tatsumi K, Ogata M, Kanemoto S, Otori K, Iseki K, Wanaka A, Imaizumi K. 2005. OASIS, a CREB/ ATF-family member, modulates UPR signalling in astrocytes. Nat Cell Biol 7: 186-194.

Kondo S, Saito A, Hino S, Murakami T, Ogata M, Kanemoto S, Nara S, Yamashita A, Yoshinaga K, Hara H, et al. 2007. $\mathrm{BBF} 2 \mathrm{H} 7$, a novel transmembrane bZIP transcription factor, is a new type of endoplasmic reticulum stress transducer. Mol Cell Biol 27: 1716-1729.

Kosmaczewski SG, Edwards TJ, Han SM, Eckwahl MJ, Meyer BI, Peach S, Hesselberth JR, Wolin SL, Hammarlund M. 2014. The RtcB RNA ligase is an essential component of the metazoan unfolded protein response. EMBO Rep 15: 1278-1285.

Kozak M. 1991. An analysis of vertebrate mRNA sequences: intimations of translational control. J Cell Biol 115: 887-903.

Krishnamoorthy J, Rajesh K, Mirzajani F, Kesoglidou P, Papadakis AI, Koromilas AE. 2014. Evidence for eIF2 $\alpha$ phosphorylationindependent effects of GSK2656157, a novel catalytic inhibitor of PERK with clinical implications. Cell Cycle 13: 801-806.

Krysov S, Steele AJ, Coelho V, Linley A, Sanchez Hidalgo M, Carter M, Potter KN, Kennedy B, Duncombe AS, Ashton-Key M, et al. 2014. Stimulation of surface IgM of chronic lymphocytic leukemia cells induces an unfolded protein response dependent on BTK and SYK. Blood 124: 3101-3109.

Labzin LI, Schmidt SV, Masters SL, Beyer M, Krebs W, Klee K, Stahl R, Lutjohann D, Schultze JL, Latz E, et al. 2015. ATF3 is a key regulator of macrophage IFN responses. I Immunol 195: 4446-4455.

Lee AS, Hendershot LM. 2006. ER stress and cancer. Cancer Biol Ther 5: 721-722.

Lee AH, Scapa EF, Cohen DE, Glimcher LH. 2008. Regulation of hepatic lipogenesis by the transcription factor XBP1. Science 320: 1492-1496.

Lee YY, Cevallos RC, Jan E. 2009. An upstream open reading frame regulates translation of GADD34 during cellular stresses that induce eIF2a phosphorylation. I Biol Chem 284: 6661-6673.
Lee JH, Won SM, Suh J, Son SJ, Moon GJ, Park UJ, Gwag BJ. 2010a. Induction of the unfolded protein response and cell death pathway in Alzheimer's disease, but not in aged Tg2576 mice. Exp Mol Med 42: 386-394.

Lee MW, Chanda D, Yang J, Oh H, Kim SS, Yoon YS, Hong S, Park KG, Lee IK, Choi CS, et al. 2010b. Regulation of hepatic gluconeogenesis by an ER-bound transcription factor, CREBH. Cell Metab 11: 331-339.

Lee AH, Heidtman K, Hotamisligil GS, Glimcher LH. 2011 a. Dual and opposing roles of the unfolded protein response regulated by IRE $1 \alpha$ and XBP1 in proinsulin processing and insulin secretion. Proc Natl Acad Sci 108: 8885-8890.

Lee JH, Giannikopoulos P, Duncan SA, Wang J, Johansen CT, Brown JD, Plutzky J, Hegele RA, Glimcher LH, Lee AH. 2011b. The transcription factor cyclic AMP-responsive element-binding protein $\mathrm{H}$ regulates triglyceride metabolism. Nat Med 17: 812-815.

Li D, Yin X, Zmuda EJ, Wolford CC, Dong X, White MF, Hai T. 2008. The repression of IRS2 gene by ATF3, a stress-inducible gene, contributes to pancreatic $\beta$-cell apoptosis. Diabetes 57: 635-644.

Li G, Scull C, Ozcan L, Tabas I. 2010. NADPH oxidase links endoplasmic reticulum stress, oxidative stress, and PKR activation to induce apoptosis. J Cell Biol 191: 1113-1125.

Li H, Meng Q, Xiao F, Chen S, Du Y, Yu J, Wang C, Guo F. 2011. ATF4 deficiency protects mice from high-carbohydrate-dietinduced liver steatosis. Biochem J 438: 283-289.

Li H, Chen X, Gao Y, Wu J, Zeng F, Song F. 2015. XBP1 induces snail expression to promote epithelial-to-mesenchymal transition and invasion of breast cancer cells. Cell Signal 27: 82-89.

Liang G, Audas TE, Li Y, Cockram GP, Dean JD, Martyn AC, Kokame K, Lu R. 2006a. Luman/CREB3 induces transcription of the endoplasmic reticulum (ER) stress response protein Herp through an ER stress response element. Mol Cell Biol 26: 7999-8010.

Liang SH, Zhang W, McGrath BC, Zhang P, Cavener DR. 2006b. PERK (eIF2 $\alpha$ kinase) is required to activate the stress-activated MAPKs and induce the expression of immediate-early genes upon disruption of ER calcium homoeostasis. Biochem $I$ 393: 201-209.

Liang XH, Shen W, Sun H, Migawa MT, Vickers TA, Crooke ST. 2016. Translation efficiency of mRNAs is increased by antisense oligonucleotides targeting upstream open reading frames. Nat Biotechnol 34: 875-880.

Lin YD, Chen S, Yue P, Zou W, Benbrook DM, Liu S, Le TC, Berlin KD, Khuri FR, Sun SY. 2008. CAAT/enhancer binding protein homologous protein-dependent death receptor 5 induction is a major component of SHetA2-induced apoptosis in lung cancer cells. Cancer Res 68: 5335-5344.

Liou HC, Boothby MR, Glimcher LH. 1988. Distinct cloned class II MHC DNA binding proteins recognize the $\mathrm{X}$ box transcription element. Science 242: 69-71.

Liu JT, Yang Y, Guo XG, Chen M, Ding HZ, Chen YL, Wang MR. 2011. Over-expression of atf4 in Xenopus embryos interferes with neurogenesis and eye formation. Dongwuxue Yanjiu 32: 485-491.

Lu PD, Harding HP, Ron D. 2004. Translation reinitiation at alternative open reading frames regulates gene expression in an integrated stress response. J Cell Biol 167: 27-33.

Lu Y, Liang FX, Wang X. 2014. A synthetic biology approach identifies the mammalian UPR RNA ligase RtcB. Mol Cell 55: 758-770.

Maestre L, Tooze R, Canamero M, Montes-Moreno S, Ramos R, Doody G, Boll M, Barrans S, Baena S, Piris MA, et al. 2009. 
Expression pattern of $\mathrm{XBP} 1(\mathrm{~S})$ in human B-cell lymphomas. Haematologica 94: 419-422.

Malaspina A, Ngoh SF, Ward RE, Hall JC, Tai FW, Yip PK, Jones C, Jokic N, Averill SA, Michael-Titus AT, et al. 2010. Activation transcription factor-3 activation and the development of spinal cord degeneration in a rat model of amyotrophic lateral sclerosis. Neuroscience 169: 812-827.

Malhi H, Kropp EM, Clavo VF, Kobrossi CR, Han J, Mauer AS, Yong J, Kaufman RJ. 2013. C/EBP homologous protein-induced macrophage apoptosis protects mice from steatohepatitis. J Biol Chem 288: 18624-18642.

Martinon F, Chen X, Lee AH, Glimcher LH. 2010. TLR activation of the transcription factor XBP1 regulates innate immune responses in macrophages. Nat Immunol 11: 411-418.

Mason JL, Angelastro JM, Ignatova TN, Kukekov VG, Lin G, Greene LA, Goldman JE. 2005. ATF5 regulates the proliferation and differentiation of oligodendrocytes. Mol Cell Neurosci 29: 372-380.

Masuoka HC, Townes TM. 2002. Targeted disruption of the activating transcription factor 4 gene results in severe fetal anemia in mice. Blood 99: 736-745.

Matsuguchi T, Chiba N, Bandow K, Kakimoto K, Masuda A, Ohnishi T. 2009. JNK activity is essential for Atf4 expression and late-stage osteoblast differentiation. J Bone Miner Res 24: 398-410.

Meex SJR, van Greevenbroek MMJ, Ayoubi TA, Vlietinck R, van Vliet-Ostaptchouk JV, Hofker MH, Vermeulen VMM-J, Schalkwijk CG, Feskens EJM, Boer JMA, et al. 2007. Activating transcription factor 6 polymorphisms and haplotypes are associated with impaired glucose homeostasis and type 2 diabetes in Dutch Caucasians. I Clin Endocrinol Metab 92: 2720-2725.

Mimura N, Fulciniti M, Gorgun G, Tai YT, Cirstea D, Santo L, Hu Y, Fabre C, Minami J, Ohguchi H, et al. 2012. Blockade of $\mathrm{XBP} 1$ splicing by inhibition of IRE1 $a$ is a promising therapeutic option in multiple myeloma. Blood 119: 5772-5781.

Mitsuda T, Hayakawa Y, Itoh M, Ohta K, Nakagawa T. 2007. ATF4 regulates $\gamma$-secretase activity during amino acid imbalance. Biochem Biophys Res Commun 352: 722-727.

Moreno JA, Radford H, Peretti D, Steinert JR, Verity N, Martin MG, Halliday M, Morgan J, Dinsdale D, Ortori CA, et al. 2012. Sustained translational repression by eIF2 $\alpha-P$ mediates prion neurodegeneration. Nature 485: 507-511.

Moreno JA, Halliday M, Molloy C, Radford H, Verity N, Axten JM, Ortori CA, Willis AE, Fischer PM, Barrett DA, et al. 2013. Oral treatment targeting the unfolded protein response prevents neurodegeneration and clinical disease in prion-infected mice. Sci Transl Med 5: 206ra138.

Nagamori I, Yabuta N, Fujii T, Tanaka H, Yomogida K, Nishimune Y, Nojima H. 2005. Tisp40, a spermatid specific bZip transcription factor, functions by binding to the unfolded protein response element via the Rip pathway. Genes Cells 10: 575-594.

Nakajima S, Saito Y, Takahashi S, Hiramatsu N, Kato H, Johno H, Yao J, Paton AW, Paton JC, Kitamura M. 2010. Anti-inflammatory subtilase cytotoxin up-regulates A20 through the unfolded protein response. Biochem Biophys Res Commun 397: 176-180.

Niederreiter L, Fritz TM, Adolph TE, Krismer AM, Offner FA, Tschurtschenthaler M, Flak MB, Hosomi S, Tomczak MF, Kaneider NC, et al. 2013. ER stress transcription factor Xbp1 suppresses intestinal tumorigenesis and directs intestinal stem cells. J Exp Med 210: 2041-2056.

Obacz J, Avril T, Le Reste PJ, Urra H, Quillien V, Hetz C, Chevet E. 2017. Endoplasmic reticulum proteostasis in glioblastoma-
From molecular mechanisms to therapeutic perspectives. Sci Signal 10: eaal2323.

Ohno M. 2014. Roles of eIF2 $\alpha$ kinases in the pathogenesis of Alzheimer's disease. Front Mol Neurosci 7: 22.

Oslowski CM, Hara T, O’Sullivan-Murphy B, Kanekura K, Lu S, Hara M, Ishigaki S, Zhu LJ, Hayashi E, Hui ST, et al. 2012. Thioredoxin-interacting protein mediates ER stress-induced $\beta$ cell death through initiation of the inflammasome. Cell Metab 16: 265-273.

Oyadomari S, Koizumi A, Takeda K, Gotoh T, Akira S, Araki E, Mori M. 2002. Targeted disruption of the Chop gene delays endoplasmic reticulum stress-mediated diabetes. I Clin Invest 109: 525-532.

Pahl HL, Baeuerle PA. 1995. A novel signal transduction pathway from the endoplasmic reticulum to the nucleus is mediated by transcription factor NF-кB. EMBO J 14: 2580-2588.

Palam LR, Baird TD, Wek RC. 2011. Phosphorylation of eIF2 facilitates ribosomal bypass of an inhibitory upstream ORF to enhance CHOP translation. J Biol Chem 286: 10939-10949.

Papandreou I, Denko NC, Olson M, Van Melckebeke H, Lust S, Tam A, Solow-Cordero DE, Bouley DM, Offner F, Niwa M, et al. 2011. Identification of an Irela endonuclease specific inhibitor with cytotoxic activity against human multiple myeloma. Blood 117: 1311-1314.

Park HJ, Kang YM, Kim CH, Jung MH. 2010a. ATF3 negatively regulates adiponectin receptor 1 expression. Biochem Biophys Res Commun 400: 72-77.

Park SW, Zhou Y, Lee J, Lu A, Sun C, Chung J, Ueki K, Ozcan U. $2010 \mathrm{~b}$. The regulatory subunits of PI3K, p $85 \alpha$ and $\mathrm{p} 85 \beta$, interact with XBP-1 and increase its nuclear translocation. Nat Med 16: 429-437.

Pelzer AE, Bektic J, Haag P, Berger AP, Pycha A, Schafer G, Rogatsch H, Horninger W, Bartsch G, Klocker H. 2006. The expression of transcription factor activating transcription factor 3 in the human prostate and its regulation by androgen in prostate cancer. J Urol 175: 1517-1522.

Pike LR, Singleton DC, Buffa F, Abramczyk O, Phadwal K, Li JL, Simon AK, Murray JT, Harris AL. 2013. Transcriptional upregulation of ULK1 by ATF4 contributes to cancer cell survival. Biochem J 449: 389-400.

Prasanthi JR, Larson T, Schommer J, Ghribi O. 2011. Silencing GADD153/CHOP gene expression protects against Alzheimer's disease-like pathology induced by 27 -hydroxycholesterol in rabbit hippocampus. PLoS One 6: e26420.

Qing G, Li B, Vu A, Skuli N, Walton ZE, Liu X, Mayes PA, Wise DR, Thompson CB, Maris JM, et al. 2012. ATF4 regulates MYC-mediated neuroblastoma cell death upon glutamine deprivation. Cancer Cell 22: 631-644.

Qiu Q, Zheng Z, Chang L, Zhao YS, Tan C, Dandekar A, Zhang Z, Lin Z, Gui M, Li X, et al. 2013. Toll-like receptor-mediated IRE $1 \alpha$ activation as a therapeutic target for inflammatory arthritis. EMBO J 32: 2477-2490.

Rached MT, Kode A, Xu L, Yoshikawa Y, Paik JH, Depinho RA, Kousteni S. 2010. FoxO1 is a positive regulator of bone formation by favoring protein synthesis and resistance to oxidative stress in osteoblasts. Cell Metab 11: 147-160.

Reimold AM, Iwakoshi NN, Manis J, Vallabhajosyula P, Szomolanyi-Tsuda E, Gravallese EM, Friend D, Grusby MJ, Alt F, Glimcher LH. 2001. Plasma cell differentiation requires the transcription factor XBP-1. Nature 412: 300-307.

Ri M, Tashiro E, Oikawa D, Shinjo S, Tokuda M, Yokouchi Y, Narita T, Masaki A, Ito A, Ding J, et al. 2012. Identification of Toyocamycin, an agent cytotoxic for multiple myeloma cells, as a potent inhibitor of ER stress-induced XBP1 mRNA splicing. Blood Cancer J 2: e79. 
Rinella ME, Siddiqui MS, Gardikiotes K, Gottstein J, Elias M, Green RM. 2011. Dysregulation of the unfolded protein response in $\mathrm{db} / \mathrm{db}$ mice with diet-induced steatohepatitis. Hepatology 54: 1600-1609.

Romero-Ramirez L, Cao H, Nelson D, Hammond E, Lee A-H, Yoshida H, Mori K, Glimcher LH, Denko NC, Giaccia AJ, et al. 2004. XBP1 is essential for survival under hypoxic conditions and is required for tumor growth. Cancer Res 64: 5943-5947.

Romero-Ramirez L, Cao H, Regalado MP, Kambham N, Siemann D, Kim JJ, Le QT, Koong AC. 2009. X box-binding protein 1 regulates angiogenesis in human pancreatic adenocarcinomas. Transl Oncol 2: 31-38.

Ron D. 2002. Translational control in the endoplasmic reticulum stress response. J Clin Invest 110: 1383-1388.

Ron D, Habener JF. 1992. CHOP, a novel developmentally regulated nuclear protein that dimerizes with transcription factors $\mathrm{C} / \mathrm{EBP}$ and LAP and functions as a dominant-negative inhibitor of gene transcription. Genes Dev 6: 439-453.

Rousseau J, Gagne V, Labuda M, Beaubois C, Sinnett D, Laverdiere C, Moghrabi A, Sallan SE, Silverman LB, Neuberg D, et al. 2011. ATF5 polymorphisms influence ATF function and response to treatment in children with childhood acute lymphoblastic leukemia. Blood 118: 5883-5890.

Rutkowski DT, Wu J, Back SH, Callaghan MU, Ferris SP, Iqbal J, Clark R, Miao H, Hassler JR, Fornek J, et al. 2008. UPR pathways combine to prevent hepatic steatosis caused by ER stress-mediated suppression of transcriptional master regulators. Dev Cell 15: 829-840.

Sanches M, Duffy NM, Talukdar M, Thevakumaran N, Chiovitti D, Canny MD, Lee K, Kurinov I, Uehling D, Al-awar R, et al. 2014. Structure and mechanism of action of the hydroxy-arylaldehyde class of IRE1 endoribonuclease inhibitors. Nat Commun 5: 4202.

Sayers CM, Papandreou I, Guttmann DM, Maas NL, Diehl JA, Witze ES, Koong AC, Koumenis C. 2013. Identification and characterization of a potent activator of p53-independent cellular senescence via a small-molecule screen for modifiers of the integrated stress response. Mol Pharmacol 83: 594-604.

Scaiewicz V, Nahmias A, Chung RT, Mueller T, Tirosh B, Shibolet O. 2013. CCAAT/enhancer-binding protein homologous (CHOP) protein promotes carcinogenesis in the DEN-induced hepatocellular carcinoma model. PLoS One 8: e81065.

Scheuner D, Kaufman RJ. 2008. The unfolded protein response: a pathway that links insulin demand with $\beta$-cell failure and diabetes. Endocr Rev 29: 317-333.

Schewe DM, Aguirre-Ghiso JA. 2008. ATF6a-Rheb-mTOR signaling promotes survival of dormant tumor cells in vivo. Proc Natl Acad Sci 105: 10519-10524.

Schonthal AH. 2013. Pharmacological targeting of endoplasmic reticulum stress signaling in cancer. Biochem Pharmacol 85: 653-666.

Schroder M, Kaufman RJ. 2005. The mammalian unfolded protein response. Annu Rev Biochem 74: 739-789.

Schwer B, Sawaya R, Ho CK, Shuman S. 2004. Portability and fidelity of RNA-repair systems. Proc Natl Acad Sci 101: 2788-2793.

Seijffers R, Zhang J, Matthews JC, Chen A, Tamrazian E, Babaniyi O, Selig M, Hynynen M, Woolf CJ, Brown RH Jr. 2014. ATF3 expression improves motor function in the ALS mouse model by promoting motor neuron survival and retaining muscle innervation. Proc Natl Acad Sci 111: 1622-1627.

Sendoel A, Dunn JG, Rodriguez EH, Naik S, Gomez NC, Hurwitz B, Levorse J, Dill BD, Schramek D, Molina H, et al. 2017.
Translation from unconventional 5 ' start sites drives tumour initiation. Nature 541: 494-499.

Seo J, Fortuno ES 3rd, Suh JM, Stenesen D, Tang W, Parks EJ, Adams CM, Townes T, Graff JM. 2009. Atf4 regulates obesity, glucose homeostasis, and energy expenditure. Diabetes 58: 2565-2573.

Shao M, Shan B, Liu Y, Deng Y, Yan C, Wu Y, Mao T, Qiu Y, Zhou $\mathrm{Y}$, Jiang $S$, et al. 2014. Hepatic IRE $1 \alpha$ regulates fasting-induced metabolic adaptive programs through the XBP1s-PPAR $a$ axis signalling. Nat Commun 5: 3528.

Shen X, Ellis RE, Lee K, Liu CY, Yang K, Solomon A, Yoshida H, Morimoto R, Kurnit DM, Mori K, et al. 2001. Complementary signaling pathways regulate the unfolded protein response and are required for C. elegans development. Cell 107: 893-903.

Shen J, Chen X, Hendershot L, Prywes R. 2002. ER stress regulation of ATF6 localization by dissociation of BiP/GRP78 binding and unmasking of Golgi localization signals. Dev Cell 3: 99-111.

Sheng Z, Li L, Zhu LJ, Smith TW, Demers A, Ross AH, Moser RP, Green MR. 2010. A genome-wide RNA interference screen reveals an essential CREB3L2-ATF5-MCL1 survival pathway in malignant glioma with therapeutic implications. Nat Med 16: 671-677.

Shiraishi T, Yoshida T, Nakata S, Horinaka M, Wakada M, Mizutani Y, Miki T, Sakai T. 2005. Tunicamycin enhances tumor necrosis factor-related apoptosis-inducing ligand-induced apoptosis in human prostate cancer cells. Cancer Res 65: 6364-6370.

Shuda M, Kondoh N, Imazeki N, Tanaka K, Okada T, Mori K, Hada A, Arai M, Wakatsuki T, Matsubara O, et al. 2003. Activation of the ATF6, XBP1 and grp78 genes in human hepatocellular carcinoma: a possible involvement of the ER stress pathway in hepatocarcinogenesis. J Hepatol 38: 605-614.

Sidrauski C, Walter P. 1997. The transmembrane kinase Irelp is a site-specific endonuclease that initiates mRNA splicing in the unfolded protein response. Cell 90: 1031-1039.

Sidrauski C, Cox JS, Walter P. 1996. tRNA ligase is required for regulated mRNA splicing in the unfolded protein response. Cell 87: 405-413.

Silva RM, Ries V, Oo TF, Yarygina O, Jackson-Lewis V, Ryu EJ, Lu PD, Marciniak SJ, Ron D, Przedborski S, et al. 2005. CHOP/ GADD153 is a mediator of apoptotic death in substantia nigra dopamine neurons in an in vivo neurotoxin model of parkinsonism. J Neurochem 95: 974-986.

Song B, Scheuner D, Ron D, Pennathur S, Kaufman RJ. 2008. Chop deletion reduces oxidative stress, improves $\beta$ cell function, and promotes cell survival in multiple mouse models of diabetes. J Clin Invest 118: 3378-3389.

Sood R, Porter AC, Olsen DA, Cavener DR, Wek RC. 2000. A mammalian homologue of GCN2 protein kinase important for translational control by phosphorylation of eukaryotic initiation factor-2a. Genetics 154: 787-801.

Soon RK Jr, Yan JS, Grenert JP, Maher JJ. 2010. Stress signaling in the methionine-choline-deficient model of murine fatty liver disease. Gastroenterology 139: 1730-1739.

Southwood CM, Fykkolodziej B, Maheras KJ, Garshott DM, Estill M, Fribley AM, Gow A. 2016. Overexpression of CHOP in myelinating cells does not confer a significant phenotype under normal or metabolic stress conditions. I Neurosci 36: 6803-6819.

Sun X, Liu J, Crary JF, Malagelada C, Sulzer D, Greene LA, Levy OA. 2013. ATF4 protects against neuronal death in cellular Parkinson's disease models by maintaining levels of parkin. I Neurosci 33: 2398-2407. 
Taketani K, Kawauchi J, Tanaka-Okamoto M, Ishizaki H, Tanaka Y, Sakai T, Miyoshi J, Maehara Y, Kitajima S. 2012. Key role of ATF3 in p53-dependent DR5 induction upon DNA damage of human colon cancer cells. Oncogene 31: 2210-2221.

Tamaki N, Hatano E, Taura K, Tada M, Kodama Y, Nitta T, Iwaisako K, Seo S, Nakajima A, Ikai I, et al. 2008. CHOP deficiency attenuates cholestasis-induced liver fibrosis by reduction of hepatocyte injury. Am I Physiol Gastrointest Liver Physiol 294: G498-G505.

Tang QQ, Lane MD. 2000. Role of C/EBP homologous protein (CHOP-10) in the programmed activation of CCAAT/enhancer-binding protein- $\beta$ during adipogenesis. Proc Natl Acad Sci 97: 12446-12450.

Tarn WY, Steitz JA. 1997. Pre-mRNA splicing: the discovery of a new spliceosome doubles the challenge. Trends Biochem Sci 22: 132-137.

Thameem F, Farook VS, Bogardus C, Prochazka M. 2006. Association of amino acid variants in the activating transcription factor 6 gene (ATF6) on 1q21-q23 with type 2 diabetes in Pima Indians. Diabetes 55: 839-842.

Thevenot PT, Sierra RA, Raber PL, Al-Khami AA, Trillo-Tinoco J, Zarreii P, Ochoa AC, Cui Y, Del Valle L, Rodriguez PC. 2014. The stress-response sensor chop regulates the function and accumulation of myeloid-derived suppressor cells in tumors. Immunity 41: 389-401.

Tirasophon W, Welihinda AA, Kaufman RJ. 1998. A stress response pathway from the endoplasmic reticulum to the nucleus requires a novel bifunctional protein kinase/endoribonuclease (Irelp) in mammalian cells. Genes Dev 12: 1812-1824.

Tirosh B, Iwakoshi NN, Glimcher LH, Ploegh HL. 2005. XBP-1 specifically promotes IgM synthesis and secretion, but is dispensable for degradation of glycoproteins in primary B cells. J Exp Med 202: 505-516.

Tirosh B, Iwakoshi NN, Glimcher LH, Ploegh HL. 2006. Rapid turnover of unspliced Xbp-1 as a factor that modulates the unfolded protein response. J Biol Chem 281: 5852-5860.

Tominaga H, Maeda S, Hayashi M, Takeda S, Akira S, Komiya S, Nakamura T, Akiyama H, Imamura T. 2008. CCAAT/enhancer-binding protein $\beta$ promotes osteoblast differentiation by enhancing Runx2 activity with ATF4. Mol Biol Cell 19: 5373-5386.

Toriguchi K, Hatano E, Tanabe K, Takemoto K, Nakamura K, Koyama Y, Seo S, Taura K, Uemoto S. 2014. Attenuation of steatohepatitis, fibrosis, and carcinogenesis in mice fed a methionine-choline deficient diet by CCAAT/enhancer-binding protein homologous protein deficiency. J Gastroenterol Hepatol 29: 1109-1118.

Usui M, Yamaguchi S, Tanji Y, Tominaga R, Ishigaki Y, Fukumoto M, Katagiri H, Mori K, Oka Y, Ishihara H. 2012. Atf6anull mice are glucose intolerant due to pancreatic $\beta$-cell failure on a high-fat diet but partially resistant to diet-induced insulin resistance. Metabolism 61: 1118-1128.

Uzi D, Barda L, Scaiewicz V, Mills M, Mueller T, Gonzalez-Rodriguez A, Valverde AM, Iwawaki T, Nahmias Y, Xavier R, et al. 2013. CHOP is a critical regulator of acetaminophen-induced hepatotoxicity. J Hepatol 59: 495-503.

Valdes P, Mercado G, Vidal RL, Molina C, Parsons G, Court FA, Martinez A, Galleguillos D, Armentano D, Schneider BL, et al. 2014. Control of dopaminergic neuron survival by the unfolded protein response transcription factor XBP1. Proc Natl Acad Sci 111: 6804-6809.

van Galen P, Kreso A, Mbong N, Kent DG, Fitzmaurice T, Chambers JE, Xie S, Laurenti E, Hermans K, Eppert K, et al. 2014.
The unfolded protein response governs integrity of the haematopoietic stem-cell pool during stress. Nature 510: 268-272.

Vattem KM, Wek RC. 2004. Reinitiation involving upstream ORFs regulates ATF4 mRNA translation in mammalian cells. Proc Natl Acad Sci 101: 11269-11274.

Vidal RL, Figueroa A, Court FA, Thielen P, Molina C, Wirth C, Caballero B, Kiffin R, Segura-Aguilar J, Cuervo AM, et al. 2012. Targeting the UPR transcription factor XBP1 protects against Huntington's disease through the regulation of FoxO1 and autophagy. Hum Mol Genet 21: 2245-2262.

Volkmann K, Lucas JL, Vuga D, Wang X, Brumm D, Stiles C, Kriebel D, Der-Sarkissian A, Krishnan K, Schweitzer C, et al. 2011. Potent and selective inhibitors of the inositol-requiring enzyme 1 endoribonuclease. J Biol Chem 286: 12743-12755.

Walter P, Ron D. 2011. The unfolded protein response: from stress pathway to homeostatic regulation. Science 334: 1081-1086.

Wang M, Kaufman RJ. 2014. The impact of the endoplasmic reticulum protein-folding environment on cancer development. Nat Rev Cancer 14: 581-597.

Wang M, Kaufman RJ. 2016. Protein misfolding in the endoplasmic reticulum as a conduit to human disease. Nature 529: 326-335.

Wang H, Mo P, Ren S, Yan C. 2010. Activating transcription factor 3 activates p53 by preventing E6-associated protein from binding to E6. I Biol Chem 285: 13201-13210.

Wang H, Jiang M, Cui H, Chen M, Buttyan R, Hayward SW, Hai T, Wang Z, Yan C. 2012a. The stress response mediator ATF3 represses androgen signaling by binding the androgen receptor. Mol Cell Biol 32: 3190-3202.

Wang L, Perera BG, Hari SB, Bhhatarai B, Backes BJ, Seeliger MA, Schurer SC, Oakes SA, Papa FR, Maly DJ. 2012b. Divergent allosteric control of the IRE1 $\alpha$ endoribonuclease using kinase inhibitors. Nat Chem Biol 8: 982-989.

Wang S, Chen Z, Lam V, Han J, Hassler J, Finck BN, Davidson NO, Kaufman RJ. 2012c. IRE1 $\alpha-X B P 1$ s induces PDI expression to increase MTP activity for hepatic VLDL assembly and lipid homeostasis. Cell Metab 16: 473-486.

Wang SZ, Ou J, Zhu LJ, Green MR. 2012d. Transcription factor ATF5 is required for terminal differentiation and survival of olfactory sensory neurons. Proc Natl Acad Sci 109: 18589-18594.

Wang X, Guo B, Li Q, Peng J, Yang Z, Wang A, Li D, Hou Z, Lv K, Kan G, et al. 2013a. miR-214 targets ATF4 to inhibit bone formation. Nat Med 19: 93-100.

Wang Y, Zhang L, Wu X, Gurley EC, Kennedy E, Hylemon PB, Pandak WM, Sanyal AJ, Zhou H. 2013b. The role of CCAAT enhancer-binding protein homologous protein in human immunodeficiency virus protease-inhibitor-induced hepatic lipotoxicity in mice. Hepatology 57: 1005-1016.

Wang G, Liu K, Li Y, Yi W, Yang Y, Zhao D, Fan C, Yang H, Geng T, Xing J, et al. 2014. Endoplasmic reticulum stress mediates the anti-inflammatory effect of ethyl pyruvate in endothelial cells. PLoS One 9: e113983.

Wang S, Park S, Kodali VK, Han J, Yip T, Chen Z, Davidson NO, Kaufman RJ. 2015. Identification of protein disulfide isomerase 1 as a key isomerase for disulfide bond formation in apolipoprotein B100. Mol Biol Cell 26: 594-604.

Watatani Y, Ichikawa K, Nakanishi N, Fujimoto M, Takeda H, Kimura N, Hirose H, Takahashi S, Takahashi Y. 2008. Stress-induced translation of ATF5 mRNA is regulated by the 5'-untranslated region. J Biol Chem 283: 2543-2553.

Whitmore MM, Iparraguirre A, Kubelka L, Weninger W, Hai T, Williams BR. 2007. Negative regulation of TLR-signaling pathways by activating transcription factor-3. I Immunol 179: 3622-3630. 
Williams BR. 1999. PKR; a sentinel kinase for cellular stress. Oncogene 18: 6112-6120.

Willy JA, Young SK, Stevens JL, Masuoka HC, Wek RC. 2015. $\mathrm{CHOP}$ links endoplasmic reticulum stress to NF-kB activation in the pathogenesis of nonalcoholic steatohepatitis. Mol Biol Cell 26: 2190-2204.

Winnay JN, Boucher J, Mori MA, Ueki K, Kahn CR. 2010. A regulatory subunit of phosphoinositide 3-kinase increases the nuclear accumulation of X-box-binding protein- 1 to modulate the unfolded protein response. Nat Med 16: 438-445.

Wiseman RL, Zhang Y, Lee KP, Harding HP, Haynes CM, Price J, Sicheri F, Ron D. 2010. Flavonol activation defines an unanticipated ligand-binding site in the kinase-RNase domain of IRE1. Mol Cell 38: 291-304.

Wu J, Rutkowski DT, Dubois M, Swathirajan J, Saunders T, Wang J, Song B, Yau GD, Kaufman RJ. 2007. ATF6a optimizes longterm endoplasmic reticulum function to protect cells from chronic stress. Dev Cell 13: 351-364.

Wu X, Nguyen BC, Dziunycz P, Chang S, Brooks Y, Lefort K, Hofbauer GF, Dotto GP. 2010. Opposing roles for calcineurin and ATF3 in squamous skin cancer. Nature 465: 368-372.

Wu L, Tian YY, Shi JP, Xie W, Shi JQ, Lu J, Zhang YD. 2013. Inhibition of endoplasmic reticulum stress is involved in the neuroprotective effects of candesartan cilexitil in the rotenone rat model of Parkinson's disease. Neurosci Lett 548: 50-55.

Wu X, Xin Z, Zhang W, Zheng S, Wu J, Chen K, Wang H, Zhu X, Li $Z$, Duan Z, et al. 2014. A missense polymorphism in ATF6 gene is associated with susceptibility to hepatocellular carcinoma probably by altering ATF6 level. Int I Cancer 135: $61-68$.

Xiao G, Zhang T, Yu S, Lee S, Calabuig-Navarro V, Yamauchi J, Ringquist S, Dong HH. 2013. ATF4 protein deficiency protects against high fructose-induced hypertriglyceridemia in mice. I Biol Chem 288: 25350-25361.

Xie JJ, Xie YM, Chen B, Pan F, Guo JC, Zhao Q, Shen JH, Wu ZY, $\mathrm{Wu}$ JY, Xu LY, et al. 2014. ATF3 functions as a novel tumor suppressor with prognostic significance in esophageal squamous cell carcinoma. Oncotarget 5: 8569-8582.

Xu T, Yang L, Yan C, Wang X, Huang P, Zhao F, Zhao L, Zhang M, Jia W, Wang X, et al. 2014. The IRE1 $\alpha$-XBP1 pathway regulates metabolic stress-induced compensatory proliferation of pancreatic $\beta$-cells. Cell Res 24: 1137-1140.

Xu X, Park JG, So JS, Lee AH. 2015. Transcriptional activation of Fsp27 by the liver-enriched transcription factor CREBH promotes lipid droplet growth and hepatic steatosis. Hepatology 61: 857-869.

Yamaguchi H, Wang HG. 2004. CHOP is involved in endoplasmic reticulum stress-induced apoptosis by enhancing DR5 expression in human carcinoma cells. $I$ Biol Chem 279: 45495-45502.

Yamamoto K, Sato T, Matsui T, Sato M, Okada T, Yoshida H, Harada A, Mori K. 2007. Transcriptional induction of mammalian ER quality control proteins is mediated by single or combined action of ATF6 a and XBP1. Dev Cell 13: 365-376.

Yamamoto K, Takahara K, Oyadomari S, Okada T, Sato T, Harada A, Mori K. 2010. Induction of liver steatosis and lipid droplet formation in ATF6a-knockout mice burdened with pharmacological endoplasmic reticulum stress. Mol Biol Cell 21: 2975-2986.

Yamamuro A, Yoshioka Y, Ogita K, Maeda S. 2006. Involvement of endoplasmic reticulum stress on the cell death induced by 6-hydroxydopamine in human neuroblastoma SH-SY5Y cells. Neurochem Res 31: 657-664.

Yamazaki H, Hiramatsu N, Hayakawa K, Tagawa Y, Okamura M, Ogata R, Huang T, Nakajima S, Yao J, Paton AW, et al. 2009.
Activation of the Akt-NF- $\mathrm{B}$ pathway by subtilase cytotoxin through the ATF6 branch of the unfolded protein response. I Immunol 183: 1480-1487.

Yang X, Matsuda K, Bialek P, Jacquot S, Masuoka HC, Schinke T, Li L, Brancorsini S, Sassone-Corsi P, Townes TM, et al. 2004. ATF4 is a substrate of RSK2 and an essential regulator of osteoblast biology: implication for Coffin-Lowry syndrome. Cell 117: 387-398.

Ye J, Rawson RB, Komuro R, Chen X, Dave UP, Prywes R, Brown MS, Goldstein JL. 2000. ER stress induces cleavage of membrane-bound ATF6 by the same proteases that process SREBPs. Mol Cell 6: 1355-1364.

Ye J, Kumanova M, Hart LS, Sloane K, Zhang H, De Panis DN, Bobrovnikova-Marjon E, Diehl JA, Ron D, Koumenis C. 2010. The GCN2-ATF4 pathway is critical for tumour cell survival and proliferation in response to nutrient deprivation. EMBO I 29: 2082-2096.

Yin X, Dewille JW, Hai T. 2008. A potential dichotomous role of ATF3, an adaptive-response gene, in cancer development. Oncogene 27: 2118-2127.

Yin X, Wolford CC, Chang YS, McConoughey SJ, Ramsey SA, Aderem A, Hai T. 2010. ATF3, an adaptive-response gene, enhances TGF $\beta$ signaling and cancer-initiating cell features in breast cancer cells. J Cell Sci 123: 3558-3565.

Yoshida H, Matsui T, Yamamoto A, Okada T, Mori K. 2001. XBP1 mRNA is induced by ATF6 and spliced by IRE1 in response to ER stress to produce a highly active transcription factor. Cell 107: 881-891.

Yoshida H, Oku M, Suzuki M, Mori K. 2006. pXBP1(U) encoded in $\mathrm{XBP} 1$ pre-mRNA negatively regulates unfolded protein response activator pXBP1(S) in mammalian ER stress response. J Cell Biol 172: 565-575.

Yoshizawa T, Hinoi E, Jung DY, Kajimura D, Ferron M, Seo J, Graff JM, Kim JK, Karsenty G. 2009. The transcription factor ATF4 regulates glucose metabolism in mice through its expression in osteoblasts. J Clin Invest 119: 2807-2817.

You KR, Liu MJ, Han XJ, Lee ZW, Kim DG. 2003. Transcriptional regulation of the human transferrin gene by GADD153 in hepatoma cells. Hepatology 38: 745-755.

Yuan X, Yu L, Li J, Xie G, Rong T, Zhang L, Chen J, Meng Q, Irving AT, Wang D, et al. 2013. ATF3 suppresses metastasis of bladder cancer by regulating gelsolin-mediated remodeling of the actin cytoskeleton. Cancer Res 73: 3625-3637.

Zhang K, Kaufman RJ. 2008. From endoplasmic-reticulum stress to the inflammatory response. Nature 454: 455-462.

Zhang K, Wong HN, Song B, Miller CN, Scheuner D, Kaufman RJ. 2005. The unfolded protein response sensor IREl $\alpha$ is required at 2 distinct steps in B cell lymphopoiesis. J Clin Invest 115: $268-281$.

Zhang K, Shen X, Wu J, Sakaki K, Saunders T, Rutkowski DT, Back SH, Kaufman RJ. 2006. Endoplasmic reticulum stress activates cleavage of CREBH to induce a systemic inflammatory response. Cell 124: 587-599.

Zhang K, Wang S, Malhotra J, Hassler JR, Back SH, Wang G, Chang L, Xu W, Miao H, Leonardi R, et al. 2011. The unfolded protein response transducer IRE1 $\alpha$ prevents ER stress-induced hepatic steatosis. EMBO J 30: 1357-1375.

Zhang C, Wang G, Zheng Z, Maddipati KR, Zhang X, Dyson G, Williams P, Duncan SA, Kaufman RJ, Zhang K. 2012. Endoplasmic reticulum-tethered transcription factor cAMP responsive element-binding protein, hepatocyte specific, regulates hepatic lipogenesis, fatty acid oxidation, and lipolysis upon metabolic stress in mice. Hepatology 55: 1070-1082.

Zhang Q, Yu J, Liu B, Lv Z, Xia T, Xiao F, Chen S, Guo F. 2013. Central activating transcription factor 4 (ATF4) regulates 
hepatic insulin resistance in mice via S6K1 signaling and the vagus nerve. Diabetes 62: 2230-2239.

Zhao Y, Zhou J, Liu D, Dong F, Cheng H, Wang W, Pang Y, Wang $\mathrm{Y}, \mathrm{Mu} \mathrm{X}, \mathrm{Ni} \mathrm{Y}$, et al. 2015. ATF4 plays a pivotal role in the development of functional hematopoietic stem cells in mouse fetal liver. Blood 126: 2383-2391.

Zhou D, Palam LR, Jiang L, Narasimhan J, Staschke KA, Wek RC. 2008. Phosphorylation of eIF2 directs ATF5 translational control in response to diverse stress conditions. J Biol Chem 283: 7064-7073.

Zhou Y, Lee J, Reno CM, Sun C, Park SW, Chung J, Lee J, Fisher SJ, White MF, Biddinger SB, et al. 2011. Regulation of glucose homeostasis through a XBP-1-FoxO1 interaction. Nat Med 17: 356-365.

Zhu H, Chen X, Chen B, Chen B, Fan J, Song W, Xie Z, Jiang D, Li Q, Zhou M, et al. 2014a. Activating transcription factor 4 mediates a multidrug resistance phenotype of esophageal squamous cell carcinoma cells through transactivation of STAT3 expression. Cancer Lett 354: 142-152.

Zhu H, Chen X, Chen B, Chen B, Song W, Sun D, Zhao Y. 2014b. Activating transcription factor 4 promotes esophageal squamous cell carcinoma invasion and metastasis in mice and is associated with poor prognosis in human patients. PLOS One 9: e103882.

Zmuda EJ, Qi L, Zhu MX, Mirmira RG, Montminy MR, Hai T. 2010. The roles of ATF3, an adaptive-response gene, in highfat-diet-induced diabetes and pancreatic $\beta$-cell dysfunction. Mol Endocrinol 24: 1423-1433.

Zuleta A, Vidal RL, Armentano D, Parsons G, Hetz C. 2012. AAVmediated delivery of the transcription factor XBP1s into the striatum reduces mutant Huntingtin aggregation in a mouse model of Huntington's disease. Biochem Biophys Res Commun 420: 558-563. 


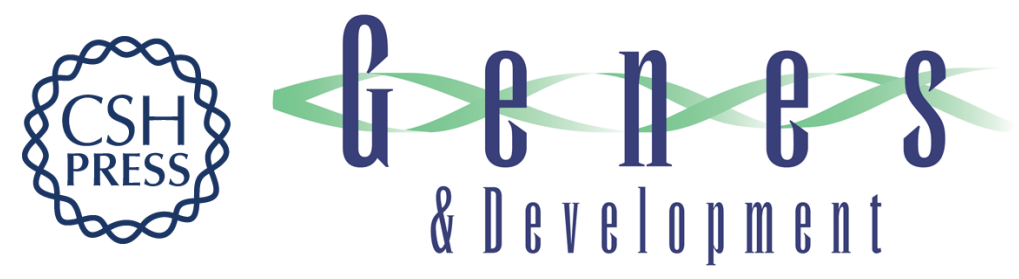

\section{Physiological/pathological ramifications of transcription factors in the unfolded protein response}

Jaeseok Han and Randal J. Kaufman

Genes Dev. 2017, 31:

Access the most recent version at doi:10.1101/gad.297374.117

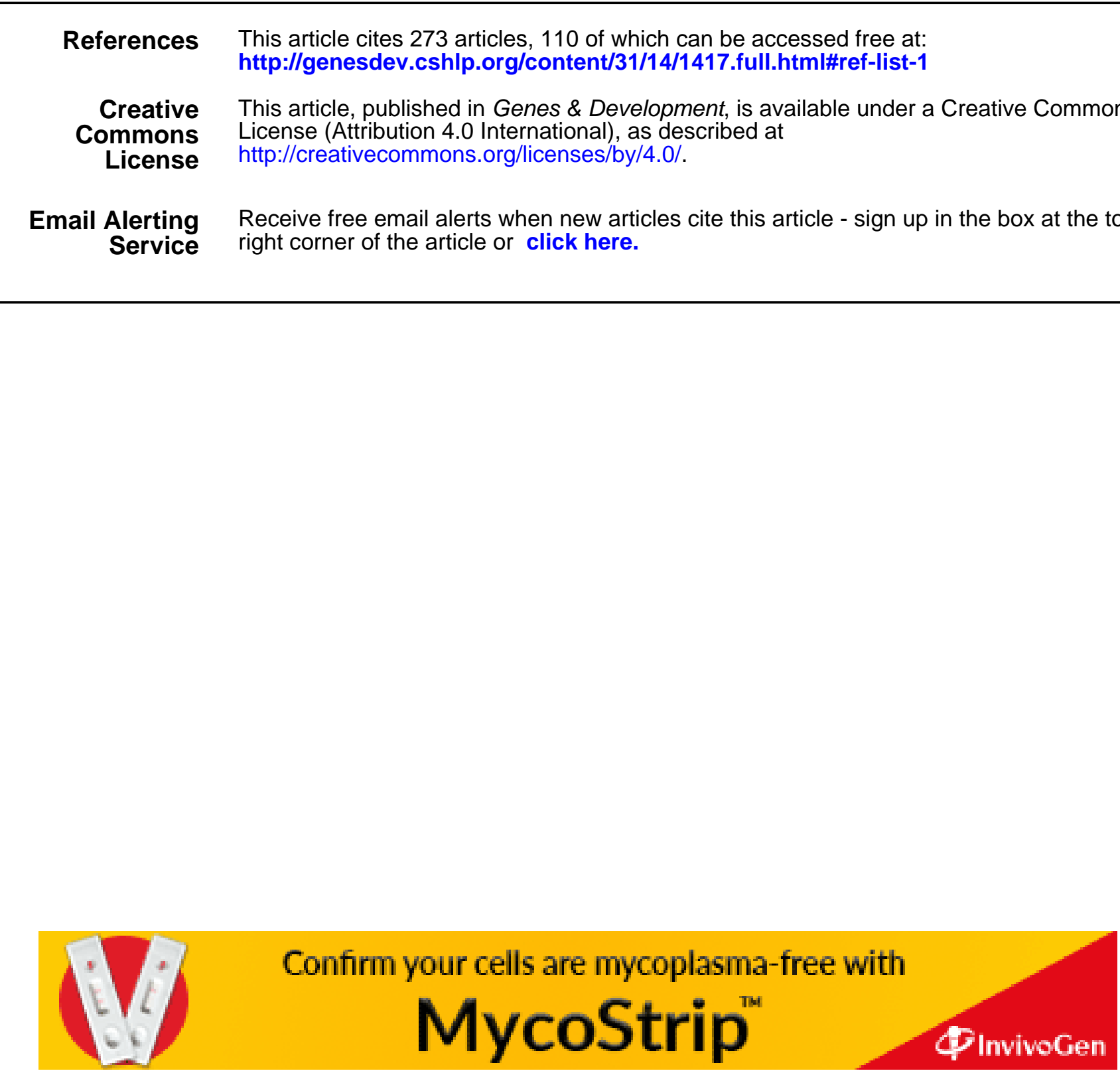

(C) 2017 Han and Kaufman; Published by Cold Spring Harbor Laboratory Press 